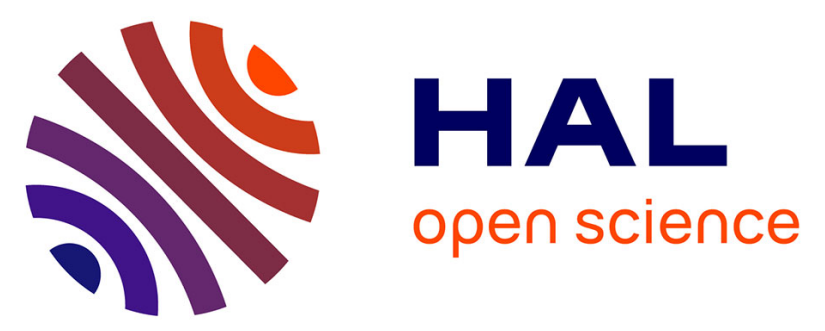

\title{
Crustal and mantle structure beneath the Terre Adélie Craton, East Antarctica: insights from receiver function and seismic anisotropy measurements
}

Gaëlle Lamarque, Guilhem Barruol, Fabrice R. R. Fontaine, Jerôme Bascou, René-Pierre Ménot

\section{To cite this version:}

Gaëlle Lamarque, Guilhem Barruol, Fabrice R. R. Fontaine, Jerôme Bascou, René-Pierre Ménot. Crustal and mantle structure beneath the Terre Adélie Craton, East Antarctica: insights from receiver function and seismic anisotropy measurements. Geophysical Journal International, 2015, 10.1093/gji/ggu430 . hal-01236105

\section{HAL Id: hal-01236105 \\ https://hal.univ-reunion.fr/hal-01236105}

Submitted on 1 Dec 2015

HAL is a multi-disciplinary open access archive for the deposit and dissemination of scientific research documents, whether they are published or not. The documents may come from teaching and research institutions in France or abroad, or from public or private research centers.
L'archive ouverte pluridisciplinaire HAL, est destinée au dépôt et à la diffusion de documents scientifiques de niveau recherche, publiés ou non, émanant des établissements d'enseignement et de recherche français ou étrangers, des laboratoires publics ou privés. 


\title{
Crustal and mantle structure beneath the Terre Adélie Craton, East Antarctica: insights from receiver function and seismic anisotropy measurements
}

\author{
Gaëlle Lamarque, ${ }^{1}$ Guilhem Barruol, ${ }^{2}$ Fabrice R. Fontaine, ${ }^{2}$ Jérôme Bascou ${ }^{1}$ \\ and René-Pierre Ménot ${ }^{1}$ \\ ${ }^{1}$ Université de Lyon, Université Jean Monnet, UMR CNRS IRD 6524, Laboratoire Magmas et Volcans, F-42023 Saint Etienne, France. E-mail: \\ gaelle.lamarque@univ-st-etienne.fr \\ ${ }^{2}$ Laboratoire GéoSciences Réunion, Université de La Réunion, Institut de Physique du Globe de Paris, Sorbonne Paris Cité, UMR CNRS 7154, Université \\ Paris Diderot, F-97744 Saint Denis, France
}

Accepted 2014 October 30. Received 2014 September 22; in original form 2014 June 18

\begin{abstract}
S UMMAR Y
The Terre Adélie and George V Land (East Antarctica) represent key areas for understanding tectonic relationships between terranes forming the Neoarchean-Palaeoproterozoic Terre Adélie Craton (TAC) and the neighbouring lithospheric blocks, together with the nature of its boundary. This region that represents the eastern border of the TAC is limited on its eastern side by the Mertz shear zone (MSZ) separating more recent Palaeozoic units from the craton. The MSZ, that recorded dextral strike-slip movement at 1.7 and $1.5 \mathrm{Ga}$, is likely correlated with the Kalinjala or Coorong shear zone in South Australia, east of the Gawler Craton and may therefore represent a frozen lithospheric-scale structure. In order to investigate the lithospheric structure of the TAC and the MSZ, we deployed from 2009 October to 2011 October four temporary seismic stations, which sampled the various lithospheric units of the TAC and of the neighbouring Palaeozoic block, together with the MSZ. We used receiver function method to deduce Moho depths and seismic anisotropy technique to infer the upper mantle deformation. Results from receiver functions analysis reveal Moho at 40-44 km depth beneath the TAC, at $36 \mathrm{~km}$ under the MSZ and at $28 \mathrm{~km}$ beneath the eastern Palaeozoic domain. The MSZ therefore delimits two crustal blocks of different thicknesses with a vertical offset of the Moho of $12 \mathrm{~km}$. Seismic anisotropy deduced from $S K S$ splitting at stations on the TAC shows fast polarisation directions $(\Phi)$ trending $\mathrm{E}-\mathrm{W}$, that is, parallel to the continental margin, and delay times $(\delta t)$ ranging from 0.8 to $1.6 \mathrm{~s}$. These results are similar to the splitting parameters observed at the permanent GEOSCOPE Dumont D'Urville station (DRV: $\Phi 95^{\circ} \mathrm{N}, \delta t 1.1 \mathrm{~s}$ ) located in the Palaeoproterozoic domain of TAC. On the MSZ, the small number of good quality measurements limits the investigation of the deep signature of the shear zone. However, the station in the Palaeozoic domain shows $\Phi$ trending $N 60^{\circ} \mathrm{E}$, which is significantly different to the $\Phi$ trending measurements from stations on the TAC, suggesting that the MSZ may also represent a major frontier between the Neoarchean-Palaeoproterozoic and Palaeozoic terranes.
\end{abstract}

Key words: Seismic anisotropy; Cratons; Continental tectonics: strike-slip and transform; Crustal structure; Antarctica.

\section{INTRODUCTION}

Constraining the seismic structure of cratons is fundamental for understanding the formation and the evolution of the continental lithosphere. A large part of the Antarctica continent, located east of the Trans-Antarctic Mountains, is cratonic and has been characterized from large-scale surface wave tomography by a thick lithosphere (Roult \& Rouland 1994; Roult et al. 1994; Ritzwoller et al. 2001; Morelli \& Danesi 2004; Debayle et al. 2005; Hansen et al. 2014). Geological studies show that East Antarctica consists of a homogeneous lithosphere, but likely derives from the accretion of numerous cratonic blocks (Mikhal'sky 2008; Boger 2011; Veevers 2012; Harley et al. 2013). In contrast, West Antarctica is characterized by thinner and younger lithosphere. The Terre Adélie Craton (TAC; $66.5-67.5^{\circ} \mathrm{S}$ and $135-146^{\circ} \mathrm{E}$ ) is situated at the edge of East Antarctica shield (Fig. 1A). It covers the Terre Adélie and the western part of George V Land and extends from Rocher X (longitude: $136^{\circ} 40^{\prime} \mathrm{E}$ ) in the west to the Mertz shear zone (MSZ; longitude: $146^{\circ} \mathrm{E}$ ) in the east (Peucat et al. 1999; Ménot et al. 2007; Duclaux et al. 2008). Recent geophysical data (Aitken et al. 2014) suggest 


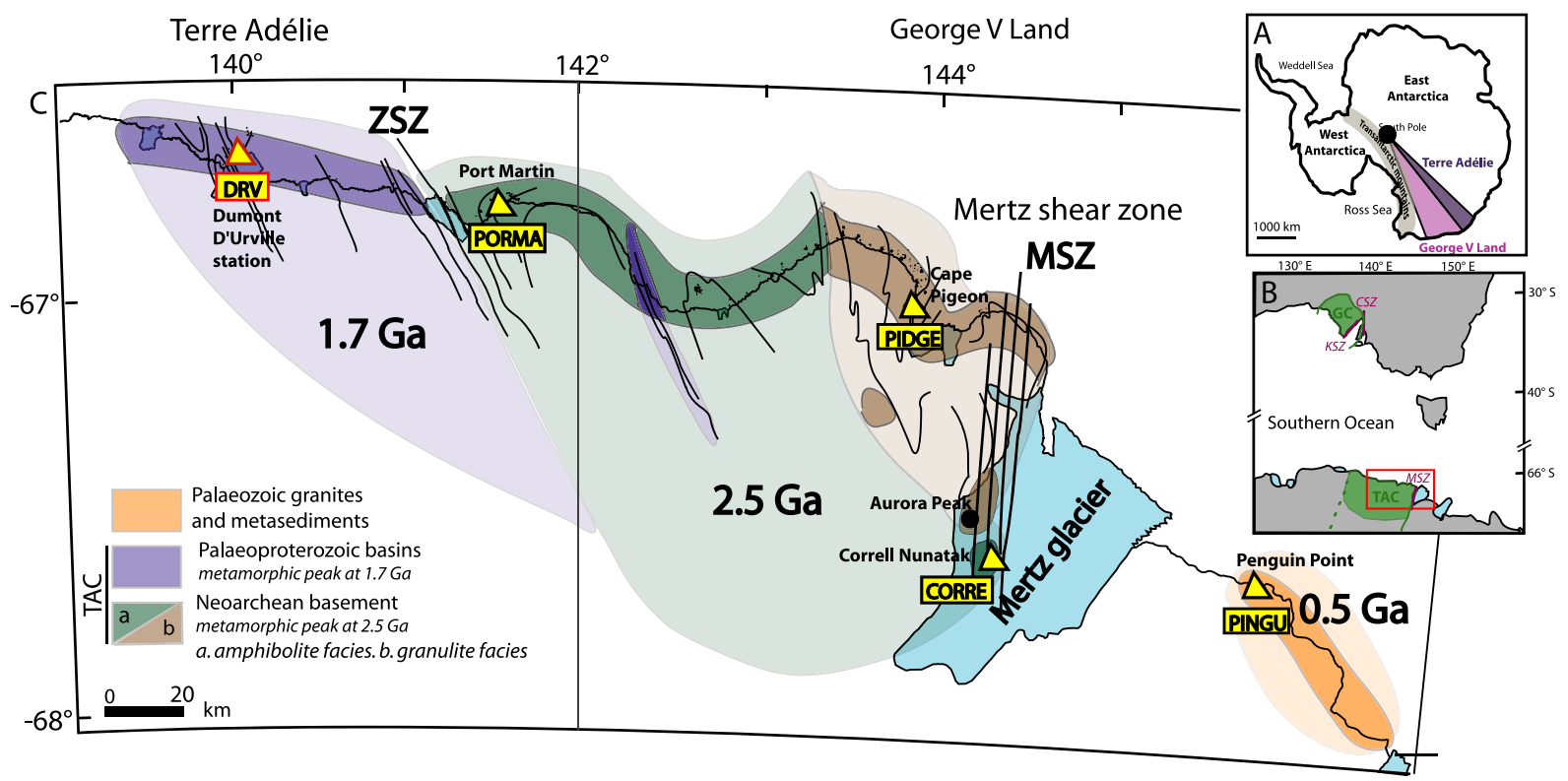

Figure 1. (A) Location of Terre Adélie and George V Land in the Antarctic continent. (B) Links between south Australia and Antarctica. TAC, Terre Adélie Craton; GC, Gawler Craton; MSZ, Mertz shear zone; KSZ, Kalinjala shear zone; CSZ, Coorong shear zone. (C) Synthetic geological map of the Terre Adélie Craton (after Ménot et al. 2007). Purple areas are Palaeoproterozoic terranes and correspond to the Dumont D'Urville and Cape Hunter Basins; green and brown areas are Archean terranes, green area referring to the intermediate to upper amphibolitic crust and brown to the granulitic crust. Orange area represents the Palaeozoic crust, mainly composed of granitoids. Darkest colours correspond to outcrops. MSZ denotes the Mertz shear zone and ZSZ denotes the Zélée shear zone. Directions of structures measured at surface are drawn in black. Seismic stations are represented by yellow triangles with a red contour for the DRV permanent station from GEOSCOPE network, and with a black contour for PORMA, PIDGE, CORRE and PINGU temporary stations used in the ArLiTA program.

that the TAC may extend westward to the Frost Fault $\left(127^{\circ} \mathrm{E}\right)$. Granitoid rocks dating from the Ross orogeny (500 Ma) outcrop to the east of the MSZ and are generally related to the geological evolution of the West Antarctica domain (Di Vincenzo et al. 2007). The MSZ thus appears to be a major boundary between the NeoarcheanPalaeoproterozoic TAC and the Early Palaeozoic units, that is, between the East Antarctica shield and the West Antarctica orogenic belts. Based on the scarce rocky outcrops in the TAC, which is mostly covered by the ice cap, the MSZ is inferred to trend roughly NS (Talarico \& Kleinschmidt 2003) and could be traced to the Kalinjala or the Coorong shear zone of south Australia (Fig. 1B) before the opening of the Southern Ocean (Kleinschmidt \& Talarico 2000; Gibson et al. 2013). The TAC likely represents the southern extension of the Gawler Craton in south Australia (Oliver \& Fanning 1997; Peucat et al. 1999; Fanning et al. 2002; Di Vincenzo et al. 2007).

The precise geometry of the blocks constituting the TAC, and their relationship to Palaeozoic domains are key questions that are difficult to answer. Since the Neoarchean and Palaeoproterozoic terranes underwent complex metamorphic and tectonic evolution, the present-day 3-D geometry of blocks boundaries is difficult to decipher by geological surface analysis alone. The ArLiTA experiment (Architecture de la Lithosphère de Terre Adélie) developed with the French polar institute (IPEV) aims at combining geological and seismological observations for improving our understanding of the deep structure of the TAC and the relationships between the different blocks that form the cratonic lithosphere. More specifically, this paper focuses on the followings.

(1) The crustal structure and in particular the depth of the Mohorovičic discontinuity (Moho depth) beneath each seismic station, and the variations in crustal thickness from block to block and across the craton boundary.
(2) The upper mantle seismic anisotropy signature (fast polarisation direction and delay time), that could be associated to large-deformation events: that is, to the Neoarchean to Palaeoproterozoic pervasive deformation, related to orogenic cycles, or to the Cretaceous lithospheric deformation linked to the rifting and opening of the Southern Ocean, or finally, to the present-day asthenospheric flow induced by plate motion relative to the deeper mantle.

(3) The crustal or lithospheric nature of a major shear zone such as the MSZ.

(4) The connection of deep structures between Antarctica and Australia which were separated during the opening of the Southern Ocean.

After a description of the geological framework of this area, we present two complementary methods which allow inference of getting information on both the crustal structure and the lithospheric deformation from respectively the receiver function technique and shear wave splitting measurements. The obtained results allow to discuss the following points: (i) the lateral variation of the crustal structure across the craton boundary, (ii) the connections between the Antarctica-Australia lithospheric structures, (iii) the possible sublithospheric origin of the mantle seismic anisotropy and (iv) the age of the upper mantle deformation beneath this area.

\section{GEOLOGICAL SETTING}

A general description of the region was made by Stillwell (1918), and more recently by Ménot et al. (2007). The TAC is divided into two domains: the Palaeoproterozoic metasedimentary basins and the Neoarchean basement (Fig. 1C). The Palaeoproterozoic metasedimentary basin extends west from the Zélée shear zone $\left(141^{\circ} \mathrm{E}\right)$ and corresponds to the highly strained and metamorphosed 
Table 1. Recording time of the four seismic stations of the temporary network of the ArLiTA program (PORMA, PIDGE, CORRE and PINGU) and of the permanent DRV seismic station from the GEOSCOPE network.

\begin{tabular}{llllll}
\hline Name & Location & Latitude $(\mathrm{N})$ & Longitude $(\mathrm{E})$ & Elevation $(\mathrm{m})$ & Running dates \\
\hline DRV & Station Dumont D’Urville & -66.665 & 140.002 & 40 & 1986 to present \\
PORMA & Port-Martin & -66.818 & 141.390 & 27 & $2009 / 11-2010 / 03$ and 2011/01-2012/01 \\
PIDGE & Cape Pigeon & -66.982 & 143.893 & 50 & $2009 / 11-2011 / 01$ \\
CORRE & Nunatak Correl & -67.583 & 144.275 & 80 & $2009 / 11-2010 / 09$ \\
PINGU & Pinguin Point & -67.596 & 146.077 & 50 & $2009 / 11-2010 / 07$ \\
\hline
\end{tabular}

Palaeoproterozoic Dumont d'Urville basin. It consists of metapelitic migmatitic gneisses with metagraywackes, silicic metavolcanic rocks and mafic intrusions. The Neoarchean basement extends from the Zélée shear zone $\left(141^{\circ} \mathrm{E}\right)$ to the $\mathrm{MSZ}\left(146^{\circ} \mathrm{E}\right)$ and is predominantly composed of felsic to mafic orthogneisses and granodiorites intruding metasedimentary rocks, which include marbles and calcsilicates. This 2.55-2.44 Ga continental crust segment (Oliver \& Fanning 2002; Duclaux et al. 2008) exposes two distinct tectonic units that equilibrated under granulite and amphibolite facies conditions, which represent deep and intermediate crustal sections, respectively (Ménot et al. 2005). A thermal and tectonic event occurred at $1.7 \mathrm{Ga}$, as proposed by Di Vincenzo et al. (2007) on the base of Ar/Ar dating. According to Duclaux et al. (2008), the $1.7 \mathrm{Ga}$ event is likely to be restricted to narrow fluid-bearing anastomosed shear zones, concentrated on the edges of the Neoarchean domain (Mertz and Zélée shear zones).

The easternmost part of the TAC is bounded by the MSZ $\left(146^{\circ} \mathrm{E}\right)$, which juxtaposed the 2.4-Ga-old granulite and amphibolite terrains to the west with a 0.5 -Ga-old intrusive complex to the east, related to the Ross Orogeny (Fanning et al. 2002; Di Vincenzo et al. 2007). The lateral extension and length of the MSZ are poorly constrained due to the scarcity of the outcrops usually ice-covered. It is well identified at the Correll and Aurora Nunataks $\left(67^{\circ} 35^{\prime} \mathrm{S}\right.$ $144^{\circ} 16^{\prime} \mathrm{E}$ and $67^{\circ} 23^{\prime} \mathrm{S} 144^{\circ} 14^{\prime} \mathrm{E}$, respectively; Fig. 1C) and could have been contiguous with the Kalinjala or Coorong shear zone (Gawler Craton, south Australia) before the Cretaceous opening of the Southern Ocean (Talarico \& Kleinschmidt 2003). The MSZ has several kilometres wide steeply dipping pervasive mylonitic foliation and subhorizontal to $20^{\circ}$ north-plunging lineation with a predominantly dextral motion (Kleinschmidt \& Talarico 2000). This suggests that the MSZ might represent a mid-crustal strike-slip fault that could have accommodated large horizontal displacements. Microstructural and thermobarometric studies (Talarico \& Kleinschmidt 2003) show that the MSZ deformation likely resulted in successive shear structures occurring under different metamorphic conditions as granulite, medium pressure amphibolite and greenschist facies up to $1.5 \mathrm{Ga}$ (Talarico \& Kleinschmidt 2003; Duclaux et al. 2008). However, Ménot et al. (2005) highlighted that a younger age (maybe post-Ordovician) cannot be formally ruled out because Palaeozoic rocks are found to the East of Mertz Glacier.

\section{SEISMIC DATA}

Within the framework of the ArLiTA project, we deployed 4 threecomponent broad-band seismic stations in Terre Adélie and George V Land from 2009 October to 2012 October along a 300-km-long profile from Port Martin to Penguin Point Eastward. The interstation spacing ranged from 60 to $100 \mathrm{~km}$, allowing the various lithospheric blocks that form the TAC to be sampled (Fig. 1C). We also included data from the GEOSCOPE permanent three-component broad-band seismic station DRV installed at the French Dumont D'Urville polar base. Temporary stations were installed on rocky outcrops to record teleseismic events optimally. They were powered by two 80 watts solar panels connected to batteries of $500 \mathrm{AH}$ to survive the polar nights between May and August. Continuous seismic signals were acquired by Guralp CMG-40 60s, three component sensors and digitized at $40 \mathrm{~Hz}$ by Taurus Nanometrics acquisition systems. The GEOSCOPE station DRV provided continuous data digitized at 20 $\mathrm{Hz}$ since 1986, first from an STS-1 sensor that was subsequently replaced by an STS-2 sensor on 2010 February 6. The temporary deployment provided 8-18 months of continuous data that we use in this study (Table 1). This group of stations have also recently been used to monitor the local and regional cryoseismic activity (Barruol et al. 2013).

\subsection{Teleseismic analysis methods}

\subsubsection{Receiver function method}

In order to estimate the depth of the main horizontal seismic boundaries in each crustal block, and particularly the Moho depth beneath each station, we used the receiver function technique. This approach aims to retrieve the $P$-to- $S$ converted phases within the coda of teleseismic $P$ waves (Langston 1977, 1979) and, therefore, the depth of the crustal discontinuities beneath a recording site, where impedance contrasts are present. The converted phases are detected by deconvolving the radial by the vertical component (Ammon 1991). This operation removes the effects of the source, the near source, the propagation path and the instrumental response. The first-order information retrieved from the receiver function is the crustal thickness. The Moho discontinuity represents one of the most significant seismic interfaces in terms of variations in elastic properties. Receiver functions are sensitive to shear velocity contrasts of interfaces located beneath the seismic station, but are only weakly sensitive to the absolute velocities (Julià et al. 2000; Tkalčić et al. 2006). Because of the increasing seismic velocity with depth, the incoming energy is refracted and the rays arrive with steeply dipping incidence at the station. For instance, for a 40-km-thick crust, the Fresnel zone width at the base of the crust (a measure of the distance from the seismic station sampled by the Pms phase) is about $10 \mathrm{~km}$.

To perform such receiver function analysis, we selected events with magnitude $\left(M_{\mathrm{b}}\right)$ greater than 5.5 and occurring at epicentral distances between $30^{\circ}$ and $90^{\circ}$ (see location Fig. 2). We kept teleseismic events with signal-to-noise ratios greater than 2 . We prepared and selected data from each station following the procedure described by Fontaine et al. (2013a): (1) we cut the waveforms 5 s prior to and 30 s after the initial $P$-wave arrival to isolate the seismic phases, (2) we rotated data into the radial-transverse reference frame and we applied a Gaussian low pass filter centred around $1.2 \mathrm{~Hz}$ in order to eliminate the influence of small-scale crustal heterogeneities. (3) We deconvolved the radial by the vertical component in the time domain (Ligorria \& Ammon 1999). (4) In order to reduce the possible effects of crustal anisotropy and of dipping seismic 


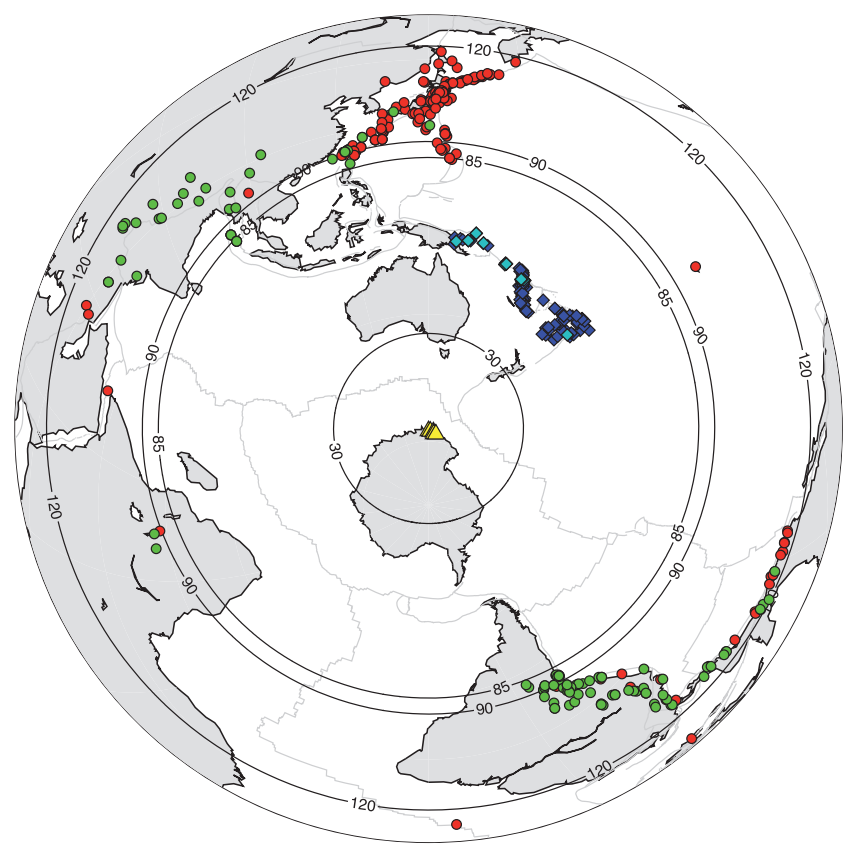

Figure 2. Location of earthquakes used for seismological analysis. Blue diamonds: events used for receiver function analysis, occurring at epicentral distances between $30^{\circ}$ and $90^{\circ}$, with a backazimuth between $\mathrm{NS}$ and $\mathrm{N} 90^{\circ} \mathrm{E}$ and with magnitude $M_{\mathrm{b}} \geq 5.5$. Light blue diamonds: events selected at PINGU station (see Fig. 3). Selected events used for SKS splitting analysis (i.e. at epicentral distances between $85^{\circ}$ and $120^{\circ}$ and magnitudes $>5.5$ ) are represented by red (null-measurements) and green circles (non-nullmeasurements). Yellow triangles represent the seismic stations.

discontinuities, we selected earthquakes with backazimuths between $\mathrm{N} 0^{\circ}$ and $\mathrm{N} 90^{\circ}$, that is, the quadrant with the highest number of data, and with a narrow range of ray-parameters (median of the ray parameters of all seismic events of the quadrant \pm 0.006 and $\pm 0.004 \mathrm{~s} \mathrm{~km}^{-1}$ at the permanent station). At DRV, we also rejected deep events (depths $>100 \mathrm{~km}$ ) mainly from the Tonga-Fidji region in order to select events with similar incidence angles. (5) We used the approach of Tkalčić et al. (2011) and kept only events with cross-correlation coefficients higher or equal to 0.70 (except at DRV station: 0.85 ) with at least 10 per cent of other RFs. The resulting radial receiver functions were then stacked. Fig. 3 shows an example of observed and stacked receiver functions at station PINGU. Shear wave velocity contrasts of interfaces and relative traveltimes of the converted waves refracted at these interfaces are constrained by individual receiver functions along the ray path. Stacking several individual receiver functions that sample similar Fresnel zones allows the strong impedance variations to be identified more easily and reduces the effects from local heterogeneities by increasing the signal-to-noise ratio.

\subsubsection{Inversion for 1-D seismic structure with six layers}

In southeastern Australia and beneath the Gawler Craton, Fontaine et al. (2013a,b) used the neighbourhood algorithm (NA; Sambridge 1999a,b) to retrieve the Moho depths and the 1-D crustal structure beneath each seismic station. Because of the non-uniqueness of the RF solution (Ammon et al. 1990), the NA method combines a Monte Carlo search technique and the properties of the Voronoi geometry in parameter space to find an ensemble of the best-fitting models and performs a global optimization. Fontaine et al. (2013b) showed good agreement between Moho depths and results from seismic reflection profiles. Here, we applied the same non-linear inversion

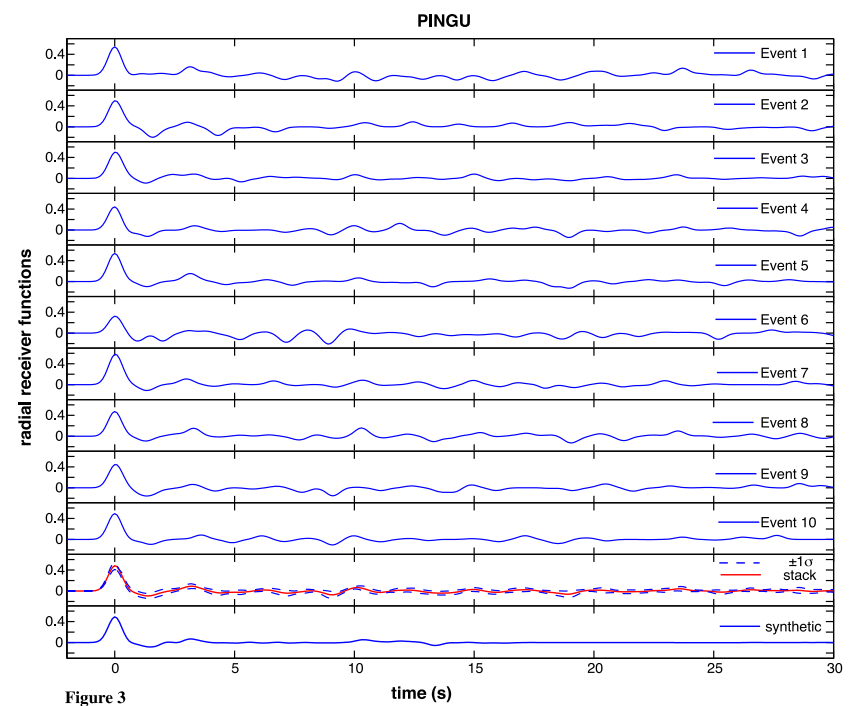

Figure 3. Observed radial RFs from the 10 selected individual events and the resulting stack at the PINGU station.

method to match the observed radial RFs. Due to the limited backazimuthal coverage obtained at the temporary ArLiTA stations, we assumed horizontal seismic discontinuities and an isotropic crust. We represented the crust and uppermost mantle structures by a six-layers, 1-D seismic velocity model (Table 2). Parameters of this model were proposed by Shibutani et al. (1996) and used by Fontaine et al. (2013b) for the Gawler Craton in southern Australia. We tested four-layers, five-layers and a different six-layers model but we obtained more realistic $S$-wave velocities with the Australian six-layers model, as shown in Fig. S1. During the NA inversion, the synthetic radial RF for each six-layers model was calculated using Thomson-Haskell matrix methods (Thomson 1950; Haskell 1953).

\subsubsection{Shear wave splitting data and method}

We processed seismic data recorded along the coasts of Terre Adélie and George V Land to detect and characterize anisotropy from teleseismic shear wave splitting. When $S K S$ waves propagating from the core-mantle boundary to the Earth's surface cross an anisotropic layer, they are split into two perpendicularly polarized shear waves propagating at different velocities. By using three component seismic records, one can retrieve the shear wave splitting parameters $\Phi$ and $\delta t$, which are the two quantitative observables of the anisotropic structure crossed by the seismic shear wave (Silver \& Chan 1991). The orientation $\Phi$ of the polarization plane of the fast split shear wave is directly related to the orientation of the pervasive fabric (foliation and lineation) of the anisotropic medium and the delay time $\delta t$ between the fast and slow split shear waves is related to the magnitude and thickness of the anisotropic layer. It is now broadly accepted from seismological and petrophysical investigations that most of the $S K S$ splitting is acquired within the upper mantle, at lithospheric and/or asthenospheric levels. Seismic anisotropy is considered to be a good proxy for upper mantle deformation (Silver 1996), providing insight into the frozen or active mantle flow that develops preferred orientations of the minerals - in particular of the predominant olivine phase-in response to tectonic strain (Nicolas \& Christensen 1987; Mainprice et al. 2000). Despite the intrinsic limitation in the vertical resolution of anisotropy, the $S K S$ waves provide reasonably good lateral resolution of few tens of kilometres, well suited to investigating lithospheric structures, 
Table 2. Model parameter space bounds used in the NA receiver function inversion to model the crust and the uppermost mantle. $V S^{\text {upper }}$ denotes the $S$-wave velocity at the top of a layer and $V s^{\text {lower }}$ that at the bottom of a layer $\left(\mathrm{km} \mathrm{s}^{-1}\right), V p / V s$ denotes the velocity ratio within a layer.

\begin{tabular}{llllr}
\hline Layer & Thickness $(\mathrm{km})$ & $V s^{\text {upper }}\left(\mathrm{km} \mathrm{s}^{-1}\right)$ & $V s^{\text {lower }}\left(\mathrm{km} \mathrm{s}^{-1}\right)$ & \multicolumn{1}{c}{$V p / V s$} \\
\hline Sediment & $0-2$ & $1.0-3.0$ & $1.0-3.0$ & $2.0-3.0$ \\
Basement & $0-3$ & $1.5-3.5$ & $1.5-3.5$ & $1.65-2.0$ \\
Upper crust & $1-15$ & $2.6-3.6$ & $2.8-4.0$ & $1.65-1.8$ \\
Middle crust & $5-20$ & $3.2-4.5$ & $3.2-4.5$ & $1.65-1.8$ \\
Lower crust & $5-20$ & $3.2-4.5$ & $3.2-4.5$ & $1.65-1.8$ \\
Mantle & $5-30$ & $2.8-5.0$ & $2.8-5.0$ & $1.7-1.9$ \\
\hline
\end{tabular}

since their Fresnel zones have radii of about $50 \mathrm{~km}$ at a depth of $100 \mathrm{~km}$ for a dominant period of $10 \mathrm{~s}$ (Margheriti et al. 2003).

From the continuous data recorded at the temporary ArLiTA stations and at the permanent GEOSCOPE station DRV, we extracted and analysed seismic events located at epicentral distances between $85^{\circ}$ and $120^{\circ}$ and with magnitudes $\left(M_{\mathrm{b}}\right.$ or $\left.M_{\mathrm{w}}\right)$ higher than 6.0 at DRV and higher than 5.5 at temporary stations (events are shown in Fig. 2). We applied the shear wave splitting analysis by first selecting records with a sufficiently good signal-to-noise ratio and then by selecting the adequate time-window including the $S K S$ phase, but avoiding any other direct $S$ or $S c S$ phases that might carry more complex anisotropic information, not located beneath the sensor. We performed the measurements using the SplitLab software (Wüstefeld et al. 2008) and the minimum eigenvalue method (Silver \& Chan 1991). This method performs a grid search over $\Phi$ and $\delta t$ that best linearizes the particle motion, that is that best corrects the anisotropy within the selected measurement window. We determined the quality of each individual measurement by applying both manual and automatic approaches, as presented by Barruol $\&$ Fontaine (2013). A manual evaluation of the quality of each individual splitting measurement is defined as good, fair or poor according to a set of criteria such as the signal-to-noise ratio of the initial waveform, the correlation between the fast and slow shear waves, the linearity of the particle motion in the horizontal plane after correction, and of the size of the 95 per cent confidence area (Barruol et al. 1997). Some examples of good measurements obtained at the DRV, PORMA and PINGU stations are shown in Fig. 4. The automatic quality factor (Auto_Q) is calculated using SplitLab (Wüstefeld et al. 2008, 2010) from the difference observed between results obtained from rotation-correlation (Bowman \& Ando 1987) and by minimizing the energy on the transverse component (Silver $\&$ Chan 1991) methods. This factor varies between -1.0 (characterizing a perfect null measurement) and 1.0 (a perfect splitting measurement providing identical results from the two techniques). Interestingly, the manual and automatic qualities show good statistical agreement overall, as shown in a previous study (Barruol et al. 2011).

We observed numerous unsplit $S K S$ waves, known as 'null' measurements, and characterized by the absence of energy on the transverse component. These null measurements may initially be interpreted as the real absence of anisotropy along the path of the seismic ray coming up to the surface at a near vertical incidence. However, this scenario requires a large number of nulls over a wide range of backazimuths, together with a real absence of non-null measurements, which is a relatively rare situation. An alternative explanation for the null measurements is that the initial polarization of the incoming wave is parallel or perpendicular to the orientation of the polarization plane in the anisotropic medium. This case is the most frequently observed (Wustefeld \& Bokelmann 2007) and can co-exist - and has to be consistent — with split $S K S$ phases. Thirdly, the presence of two anisotropic layers beneath the station with perpendicular polarization directions and similar $\delta \mathrm{t}$ in each layer may explain an apparent 'isotropic' pattern at some stations, as proposed for the CAN station in Australia (Barruol \& Hoffmann 1999). In this very specific case, the upper anisotropic layer would physically remove the splitting acquired within the lower layer. Fourthly, the presence of olivine with vertically orientated $a$-axes in the upper mantle may also explain null measurements since this crystallographic direction is almost isotropic to shear waves.

\subsection{Crustal and lithospheric structures from teleseismic analysis}

\subsubsection{Receiver function results: Moho depths and crustal structure in the TAC}

We present results from the non-linear inversions from west to east. Details of crustal thicknesses are summarized in Table 3 and vertical 1-D profiles, stacks and modelled RFs are represented in Fig. 5.

$D R V$. At DRV station (Dumont d'Urville base), 34 radial RFs were stacked. The observed receiver functions show two peaks at 3.0 $\mathrm{s}$ and between 4.5 and $5.5 \mathrm{~s}$ after the $P$-wave arrival time. These two phases have similar amplitude. To determine which one may corresponds to the Pms phase ( $P$ wave converted at the Moho discontinuity into a $S$ wave), we made a systematic detailed inspection of individual receiver functions (RFs). We conclude that the wave arriving between 4.5 and $5.5 \mathrm{~s}$ after the direct $P$ arrival is most likely to be the Pms because of its clear presence in all individual RFs, which is not the case for the first peak at $3.0 \mathrm{~s}$. We observe however, some variations in the arrival times for each event (between 4.5 and $5.5 \mathrm{~s}$ ) that may explain a smooth double peak as we stack all the individual RFs. This explains why the Pms arrival is less visible in the stacked RFs than in individual RFs (Fig. S2). The best model (with the smallest misfit) retrieves well the presence and the amplitude of the phases. However, the two firsts peaks are modelled slightly too early at 2.5 and $4.5 \mathrm{~s}$. Discontinuities are thus estimated too shallow with the best model in the plot showing the ensemble of crustal models. If the mean model does not evidence strong variation in $S$-wave velocity at the Moho, the plot showing the ensemble of the best 1000 models at DRV station shows an ensemble of 1-D models which is well constrained from the surface to around $43 \mathrm{~km}$ depth. We also analysed RF from events with backazimuths ranging from $270^{\circ}$ to $360^{\circ}$ (fourth quadrant) in order to evaluate azimuthal variations. Results in Moho depth were very similar to results from first quadrant and thus suggest no strong lateral structure variations beneath DRV. The estimated Moho depth also corresponds to a small 

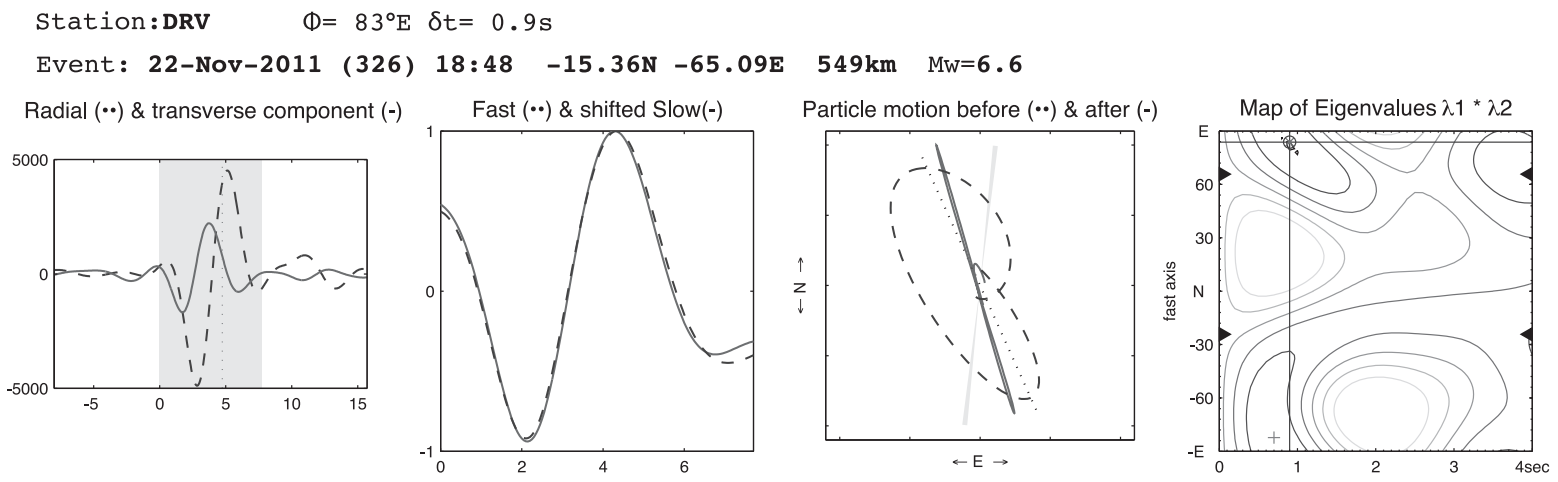

Station: PORMA $\Phi=-64^{\circ} \mathrm{E} \delta \mathrm{t}=0.8 \mathrm{~s}$

Event: $08 \div$ Nov-2011 (312) $02: 59 \quad 27.32 \mathrm{~N} \quad 125.62 \mathrm{E} \quad 224 \mathrm{~km} \quad \mathrm{MW}=6.9$
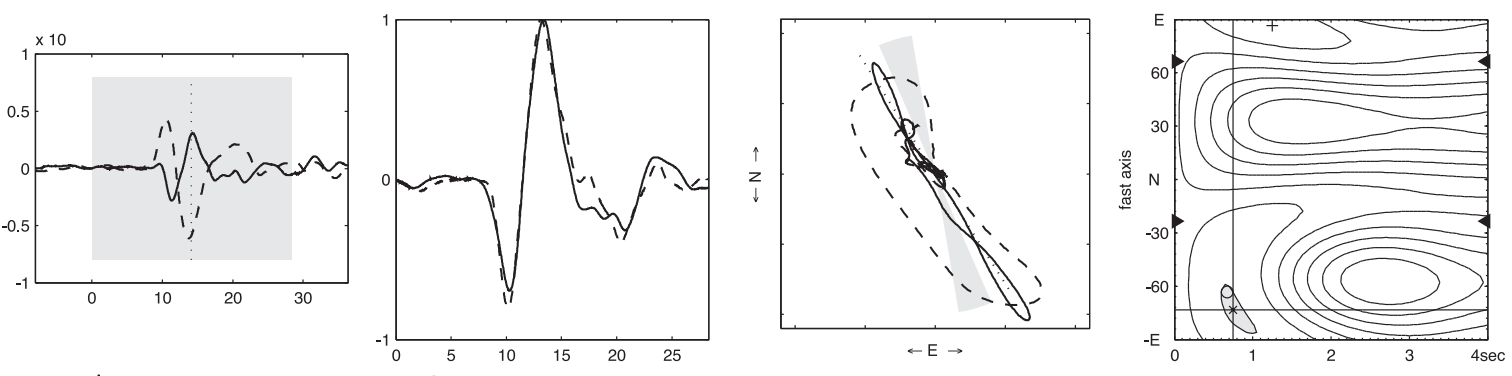

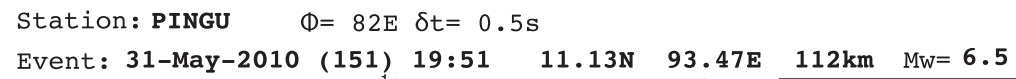
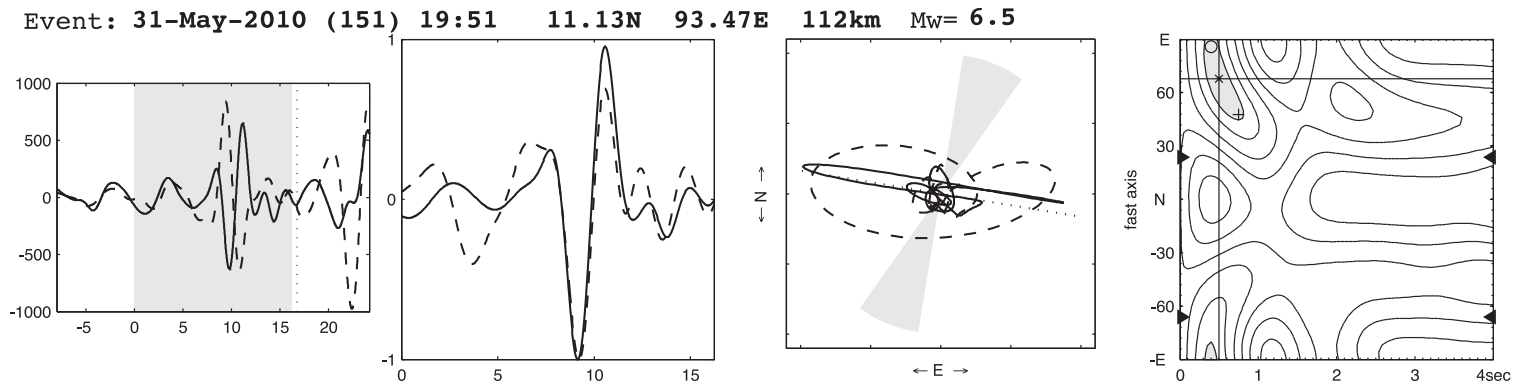

Figure 4. Examples of good measurements of SKS splitting recorded at DRV, PORMA and PINGU stations on 2011 November 22, 2011 November 8 and 2010 May 31. For the minimum eigenvalues methods, we show from left to right the seismogram of the radial (dashed line) and transverse components (solid line), the fast (dashed line) and slow components of the SKS phase, the particle motion in the horizontal plane before (dashed line) and after the anisotropy correction, the map of the eigenvalues for the various $\Phi$ and $\delta t$ values.

Table 3. Results of the RF modelling with the NA inversion. $H$ is the crustal thickness and $N$ is the number of individual RFs used for the stacking at each station. Nature represents the character of the crust-mantle transition thickness from the shear wave velocity model obtained at each station: sharp $\leq 2 \mathrm{~km}$, intermediate $2-10 \mathrm{~km}$ and broad $\geq 10 \mathrm{~km}$ (Clitheroe et al. 2000).

\begin{tabular}{llllll}
\hline Station & DRV & PORMA & PIDGE & CORRE & PINGU \\
\hline$N$ & 34 & 26 & 18 & 12 & 10 \\
$H$ & 43 & 44 & 40 & 36 & 26 \\
Nature & Broad & Intermediate & Broad & Intermediate & Intermediate \\
\hline
\end{tabular}

change between a layer with a $S$-wave velocity slightly increasing and a layer with a constant $S$-wave velocity. At this depth, some of the best 1000 models reach $S$-wave velocities at around $4.4 \mathrm{~km} \mathrm{~s}^{-1}$, which is a characteristic velocity for upper mantle. We can thus consider that the Moho is located at this boundary between well and poorly constrained models and at this small change in relative $S$-wave velocity, that is, at around $43 \mathrm{~km}$ depth. Interestingly, this value is close to the $42 \mathrm{~km}$ depth determined at the same station by Reading (2004) using receiver function analysis, and within the intrinsic accuracy of the RF method, which can be estimated at $\pm 2 \mathrm{~km}$ at the frequencies considered (Reading 2004; Fontaine et al. 2013a). It can also be noted that the author also identified a complex signature for the Pms phase, with a larger peak at $5.7 \mathrm{~s}$ preceded by a dip in the signal at $4.0 \mathrm{~s}$ and another smaller peak at $4.5 \mathrm{~s}$. She interpreted this signal as being caused by reverberations. This study shows that the Moho discontinuity is not clearly defined in the $S$-wave velocity model and suggests a progressive transition between 32 and $48 \mathrm{~km}$. This crust-mantle transition can thus be characterized as being 'broad' according to the classification initially proposed by Shibutani et al. (1996) and modified by 
a)

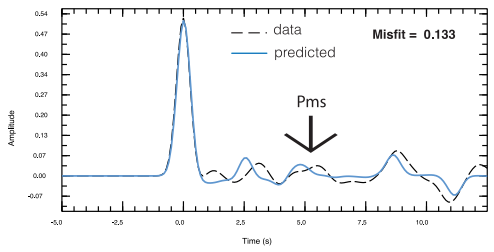

b)

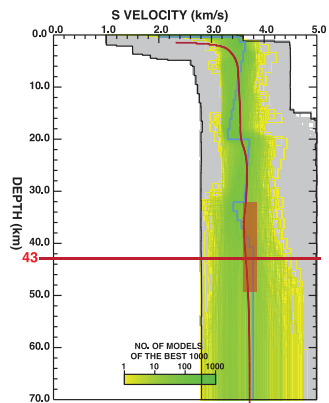

c)

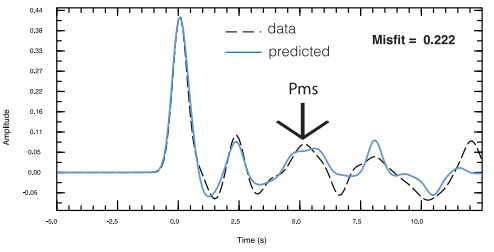

d)

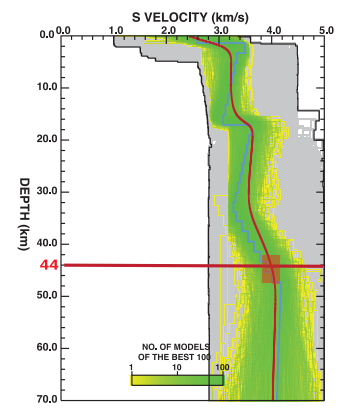

e)

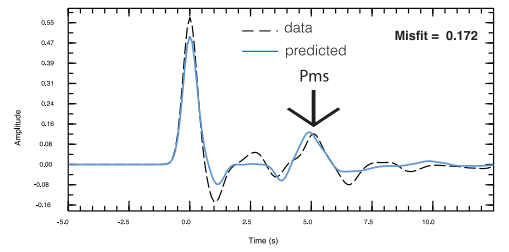

f)

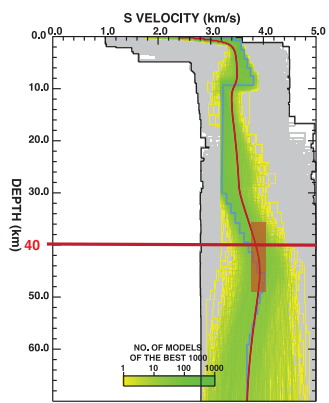

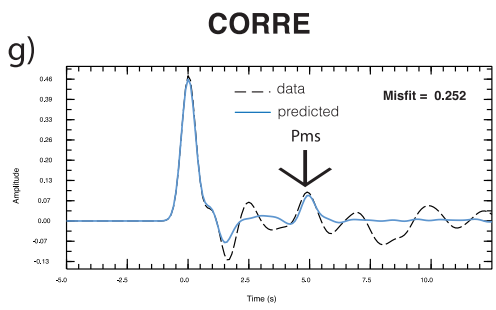

h)

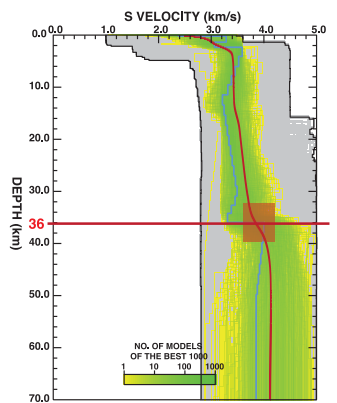

i)

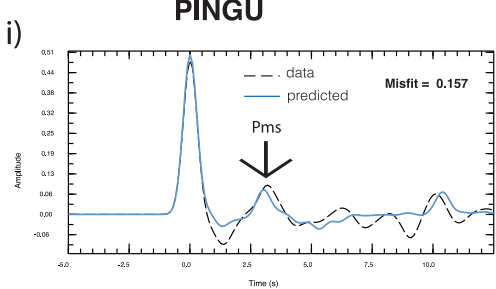

j)

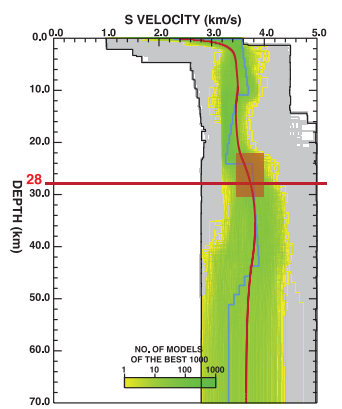

Figure 5. (a), (c), (e), (g) and (i) Comparison between the observed (black) and the predicted (blue) radial RFs from the best result (smaller misfit) of Neighbourhood Algorithm inversion at each station. Arrows indicate Pms arrival. (b), (d), (f), (h) and (j) The 1-D shear wave velocity models obtained by the inversion of teleseismic RFs at each station. All the models tested are represented in grey; the best 1000 models are shown in yellow and green, with the colour being logarithmically proportional to the model number. The colour scale shows the increase in data fit from yellow to green. For indication, the solid blue and red lines represent, respectively, the best and the mean model. Moho depths are shown in red and the red rectangle corresponds to the minimum size of the crust-mantle transition at each station.

Clitheroe et al. (2000), for which Moho thicknesses are defined as sharp $\leq 2 \mathrm{~km}$, intermediate $2-10 \mathrm{~km}$ or broad $\geq 10 \mathrm{~km}$. This classification was also used for the Gawler Craton by (Fontaine et al. 2013a). The plot showing the ensemble of crustal models also suggests a crustal structure with seismic discontinuities at 20 and 32 $\mathrm{km}$ deep beneath the DRV station.

PORMA. PORMA station (at Port Martin) presents a stacked RF (from 26 individual RFs) that clearly shows three peaks with time arrivals at 2.5, 5.0 and $8.5 \mathrm{~s}$. All of them are well modelled from the best 100 models and the Moho is estimated to be $44 \mathrm{~km}$ deep, where the S-wave velocity reaches $4.4 \mathrm{~km} \mathrm{~s}^{-1}$. The thickness of the Moho transition determined from the inversion is found to be intermediate, between 5 and $10 \mathrm{~km}$ thick. Three layers with internal discontinuities at depths of 16 and $34 \mathrm{~km}$ characterize the crust beneath PORMA station.

PIDGE. PIDGE station, located at Cape Pidgeon in the granulite core of the TAC, recorded a clear Pms peak at $5 \mathrm{~s}$ after the $P$ wave arrival, well visible in the 18 stacked RFs. Another peak is visible at $2.5 \mathrm{~s}$. The best model explains well the arrival time of the Pms but the first peak (at $2.5 \mathrm{~s}$ ) is not so well modelled. The plot showing the ensemble of the 1000 best crustal models indicates that the inversion results (Fig. 5f) is well constrained in the crust, and the Moho is marked by three changes: (1) the confidence area given by the plot showing the ensemble of crustal models around the mean model increases and thus the model is less constrained below $40 \mathrm{~km}$. (2) The $S$-wave velocity increases slightly from 12 to $40 \mathrm{~km}$ and is constant beyond $40 \mathrm{~km}$ depth. (3) At $40 \mathrm{~km}, S$-wave velocities 


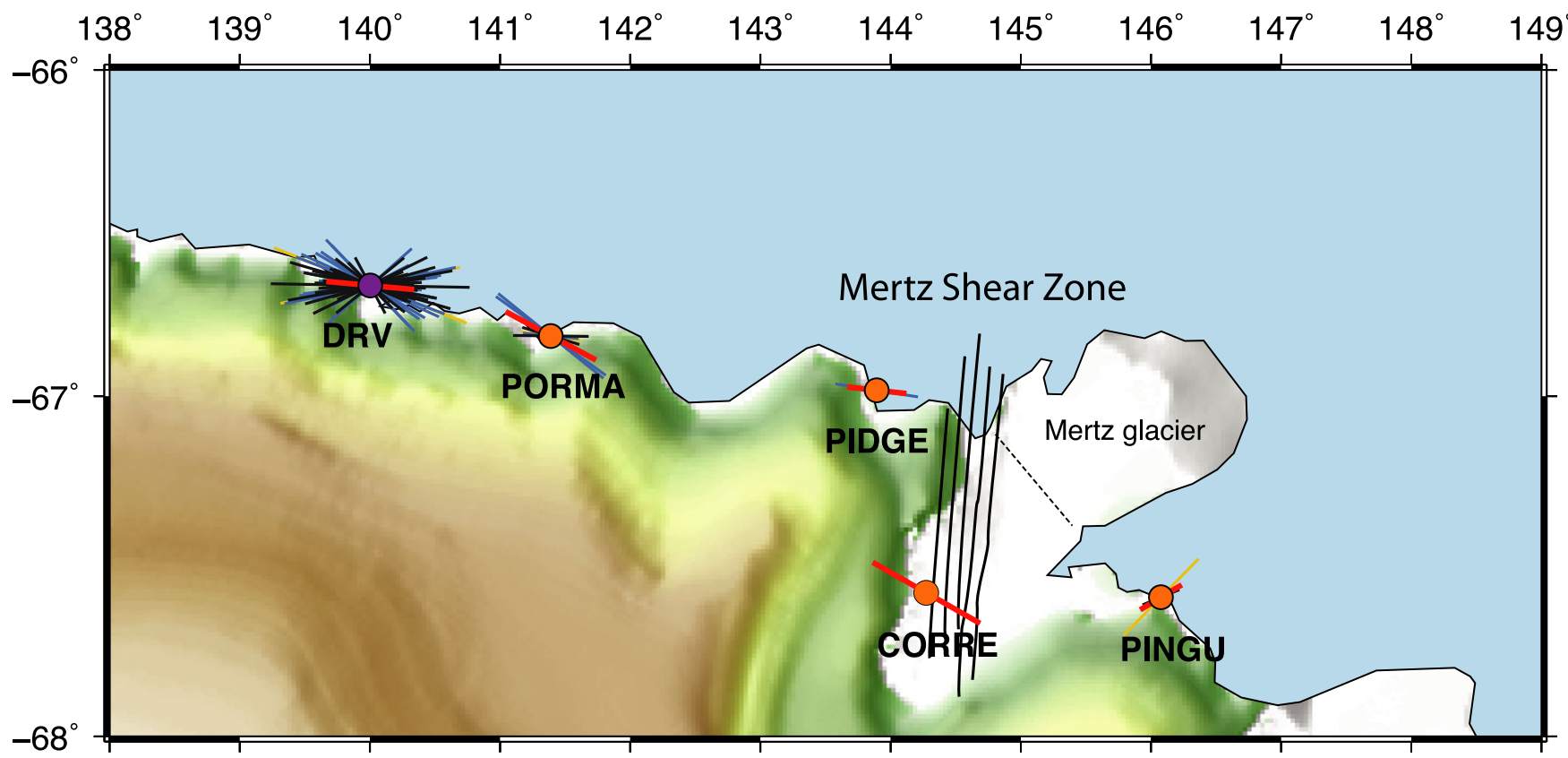

Figure 6. Map of $S K S$ splitting measurements observed at Terre Adélie and George V Land stations. Purple circle: GEOSCOPE DRV station. Orange circles: ArLiTA temporary stations. The good, fair and poor individual measurements are shown as black, blue and yellow segments, respectively. The length of the segment represents the amplitude of the delay time, and its direction the azimuth of the fast split shear wave (see Table S1 for individual measurement details). Mean measurements at each station are shown by the bold red segment (see Table 4 for mean values). The floating ice tongue of the Mertz Glacier broke in 2010 February. The dashed line indicates the location of the fracture.

in faster models reach $4.4 \mathrm{~km} \mathrm{~s}^{-1}$, which is characteristic of upper mantle velocity. These three features show a broad crust to mantle transition at $40 \mathrm{~km}$ depth. Based on the plot showing the ensemble of crustal models, the crustal structure is dominated by two layers, with an internal crustal discontinuity at $12 \mathrm{~km}$.

CORRE. The RF at CORRE station on Correll Nunatak is composed of the stack of 12 individual RFs. This stack reveals a clear $P m s$ arriving $5 \mathrm{~s}$ after the $P$ wave. This peak is well constrained by the best fitting model and corresponds in the plot showing the ensemble of crustal models (Fig. 5h) to a Moho depth of $36 \mathrm{~km}$. The waveform of the stacked RFs suggests that the crust contains at least one internal discontinuity but the peak at $2.5 \mathrm{~s}$ is not well constrain by the models. The Moho transition is intermediate. We also analysed the RFs of the few events with backazimuths between $270^{\circ}$ and $360^{\circ}$ (fourth quadrant) that sample the Fresnel zone in the TAC. Results suggest a Moho around $40 \mathrm{~km}$ on the western side, deeper than the Moho depth on the eastern side $(36 \mathrm{~km})$ estimated for events within the northeast quadrant, suggesting that the NStrending MSZ could be associated to some abrupt change in crustal thickness.

PINGU. We determined the structure of the Palaeozoic crust beneath PINGU station (at Penguin Point) from 10 RFs stacked together. A large peak is clearly visible at $3.2 \mathrm{~s}$ in the observed RF and corresponds to the arrival time of the Pms. This peak links well to the discontinuity modelled in the plot showing the overall crustal models at around $28 \mathrm{~km}$ depth. The Moho here has an intermediate thickness. Therefore, the RF analysis at PINGU station has different characteristics in comparison to the stations further west: a much reduced crustal thickness $(28 \mathrm{~km})$, no strong internal $S$-wave velocity discontinuities within the crust, and a thinner crust to mantle transition. These characteristics suggest a clearly different crust beneath PINGU station compared to that beneath the stations installed on the TAC.

\subsubsection{SKS-wave splitting results: anisotropy beneath the ArLiTA network and the DRV station}

Two decades of data recorded by DRV station provided numerous clearly split $S K S$ phases of high quality ( 91 individual split measurements, 44 of which are of good quality) representing an average of about two good measurements per year. In contrast, the temporary deployment of the ArLiTA stations in this harsh environment provided only $8-18$ months of continuous data (see Table 1 ), which is too short to obtain many good split events. This reason explain why we only detected a small number of split $S K S$ phases at the ArLiTA stations: seven at PORMA, three at PIDGE, one at CORRE and three at PINGU, and even fewer good quality split measurements (three at PORMA and two at PINGU).

A further geometrical limitation results from the event epicentral distances that may be used for $S K S$ splitting measurements, ranging between $85^{\circ}$ and $120^{\circ}$. The events located at these distances and recorded by our seismic network (Fig. 2) are predominantly characterized by backazimuths close to NS, resulting mainly in unsplit waves, that is in null results. This is the case for the numerous events originating from the Japan, Kurile, Izu-Bonin and Ryukyu trenches. Most of the non-null measurements are obtained from events occurring in South America and the India-Asia collision (Fig. 2). The few split measurements of variable quality observed at the temporary ArLiTA stations suggest that the mantle beneath this area is not isotropic, and that fast polarization direction is likely oriented close to E-W, as clearly seen at DRV.

All non-null splitting measurements are presented in Table S1 and projected for the five studied stations (Fig. 6) together with 
Table 4. Mean values of $S K S$ anisotropy measurements are given. Azimuth $(\Phi)$ is in degrees from the North and $\delta t$ is in seconds. Standard deviation $(\sigma)$ is also indicated. Mean values are weighted with the measurement quality.

\begin{tabular}{llllllll}
\hline Station & Lat $\left({ }^{\circ} \mathrm{N}\right)$ & Long $\left({ }^{\circ} \mathrm{E}\right)$ & Mean $\Phi\left({ }^{\circ}\right)$ & $\sigma \Phi\left(^{\circ}\right)$ & Mean $\delta t(\mathrm{~s})$ & $\sigma \delta t(\mathrm{~s})$ & Number of events \\
\hline DRV & -66.665 & 140.010 & 95 & 9 & 1.1 & 0.2 & 91 \\
PORMA & -66.817 & 141.390 & 118 & 7 & 1.3 & 0.2 & 7 \\
PIDGE & -66.982 & 143.893 & 96 & 17 & 0.8 & 0.4 & 3 \\
CORRE & -66.982 & 143.893 & 120 & 20 & 1.6 & 0.4 & 1 \\
PINGU & -67.596 & 146.077 & 59 & 15 & 0.6 & 0.2 & 3
\end{tabular}

the weighted mean splitting values calculated at each station and reported in Table 4.

At DRV, seismic anisotropy is clearly defined by good quality measurements, and shows consistent fast directions of anisotropy oriented close to EW. The average values of $\Phi$ of $\mathrm{N} 95 \pm 9^{\circ} \mathrm{E}$ and $\delta t$ of $1.1 \pm 0.2 \mathrm{~s}$ are fully consistent with results previously presented for this station by Barruol \& Hoffmann (1999) (N088 E, $1.16 \mathrm{~s}$, from 31 measurements), and Müller (2001) (N100 E, $0.92 \mathrm{~s}$ from four measurements).

At the ArLiTA temporary stations, despite the sparsity of high quality splitting measurements, the fast directions of anisotropy also trend close to $\mathrm{E}-\mathrm{W}$ on average for stations on the craton: from west to east, we found mean splitting parameters of $\mathrm{N} 118 \pm 7^{\circ} \mathrm{E}$ and $1.3 \pm 0.2 \mathrm{~s}$ at PORMA, N096 $\pm 17^{\circ} \mathrm{E}$ and $0.8 \pm 0.4 \mathrm{~s}$ at PIDGE and at station CORRE located on the craton boundary itself, N120 $\pm 20^{\circ} \mathrm{E}$ and $1.6 \pm 0.4 \mathrm{~s}$. Such observations, together with the absence of any correlation of $\Phi$ with the pervasive lithospheric structures seen in outcrops, lead us to conclude that Palaeoproterozoic (or Palaeozoic) anisotropy is probably not dominant in the upper mantle beneath this area. This may suggest that anisotropy is related to a post-Palaeoproterozoic lithospheric thinning that may have erased the pervasive deformation. As discussed below, the thinning of the lithosphere at the continental margin during the Gondwana breakup and the subsequent ocean opening may correspond to such scenario. At the PINGU station, located off-craton, the anisotropy trends $\mathrm{N} 59 \pm 15^{\circ} \mathrm{E}$ with a lower $\delta t(0.6 \pm 0.2 \mathrm{~s})$, which can be considered as being statistically different from the stations located on the TAC that show mean splitting results trending $\mathrm{E}-\mathrm{W}$ to $\mathrm{N} 120^{\circ} \mathrm{E}$. Interestingly, the NE-SW trend at PINGU is similar to the trend measured using $S K S$ splitting studies by Pondrelli et al. (2006), Barklage et al. (2009), Salimbeni et al. (2010) in the Victoria Land region, which is part of the same Ross orogeny as at the PINGU station. However, in Victoria Land, SKS measurements were made farther from the Southern Ocean margin. The delay measured at Victoria Land is about 1 to up to $2 \mathrm{~s}$, which is larger than our estimations. The small $\delta$ t recorded at PINGU station could be due to a destructive interference between the NE-SW signature from the Ross orogeny, which is completely recorded at Victoria Land, and the E-W Southern Ocean signature recorded all along the coast. The small number of good quality measurements obtained at PIDGE and CORRE stations does not allow to confidently argue in favour of strong variation in the splitting parameters across the craton boundary nor for clearly different anisotropy at the station CORRE installed on the MSZ itself. More seismic recordings would be necessary to precise the anisotropy pattern beneath these sites.

Analysing continuous seismic records from 1991 to 2012 at the DRV station allowed us to obtain 44 individual splitting measurements of high quality and about 50 events of fair quality. This high number of splitting measurements allows us to investigate the potential presence of several layers of anisotropy. It could explain the slight scattering of the splitting parameters observed at this site. It could also provide insights into the presence of several frozen and/or

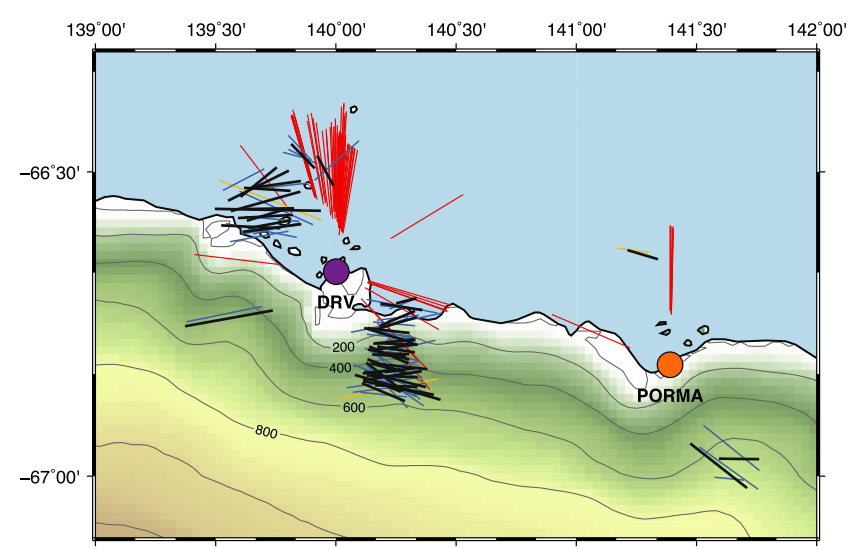

Figure 7. Map of $S K S$ splitting observed at DRV (purple circle) and PORMA (orange circle) projected to $100 \mathrm{~km}$ depth. The good, fair and poor individual measurements are shown as black, blue and yellow segments, respectively. The length of the segment represents the amplitude of the delay time, and its direction the azimuth of the fast split shear wave for non-null measurements. Red lines represent null measurements (good ones). Their direction shows the backazimuth of the corresponding event.

active pervasive structures beneath this region. Fig. 7 presents the SKS splitting observed at DRV and PORMA projected at $100 \mathrm{~km}$ depth, showing that most of the null measurements arrive from the north and that the non-null measurements arrive either from the NW or from the SE. We tested the presence of two anisotropic layers beneath DRV using the approach described by Walker et al. (2005) and by Fontaine et al. (2007). We calculated the apparent backazimuthal $\Phi$ and $\delta$ t variations for two anisotropic layers by varying $\Phi$ in each layer by increments of $2^{\circ}$ (from 0 to $180^{\circ}$ ) and $\delta t$ by increments of $0.2 \mathrm{~s}$ (from 0.2 to $2.6 \mathrm{~s}$ ). Each of the 1.3 million models tested has been compared with the splitting observations and sorted as a function of their misfit. We quantified the fit by using the coefficient of determination $R^{2}$ adjusted as detailed by Fontaine et al. (2007). This coefficient varies between $-\infty$ and 1 , and is positive when the two-layer model better explains the observations than a single layer model. At DRV, the best model we found is characterized by $\Phi_{\text {upp }} \mathrm{N} 162^{\circ} \mathrm{E}, \delta t_{\text {upp }} 0.2 \mathrm{~s}$ and $\Phi_{\text {low }} \mathrm{N} 84^{\circ} \mathrm{E}, \delta t_{\text {low }} 1.2 \mathrm{~s}$ and has a $R_{\text {adjusted }}^{2}$ of 0.17 . By analysing the 200 best models within the 95 per cent confidence interval, we found that the $R^{2}$ adjusted range between 0.07 and 0.17 , suggesting that they all slightly better explain the observations than the single layer. From these 200 models, we evidenced two dominant families of structures. The first group, to which the best model belongs, is characterized by perpendicularly oriented $\Phi$ in each layer and by $\delta t$ which may subtract from each other to result in the $1.0 \mathrm{~s}$ of total $\delta t$. This group can be represented by an EW-trending $\Phi$ in the lower layer and a fairly high $\delta t$, and by a nearly NS-trending $\Phi$ in the upper layer associated with a small $\delta t$. In this geometry, the upper layer $\delta \mathrm{t}$ is physically removed from the lower layer $\delta t$, resulting in an apparent $\delta \mathrm{t}$ of about $1.0 \mathrm{~s}$. Interestingly, it can be noted that the direction $\mathrm{N} 160^{\circ} \mathrm{E}$ corresponds to 
the large-scale outcropping crustal structures (Ménot et al. 2007; Bascou et al. 2013). The second group of models, to which belongs a majority of models, indicates fast directions close to EW in both the lower and upper layer and delay times in each layer that could add together to provide a total $\delta t$ close to $1.0 \mathrm{~s}$. The fact that the fast polarization orientations in the two layers could be very close to each other (within $15^{\circ}$ ) is consistent with the positive but small values of $R^{2}$ adjusted that suggest that the two layers explain slightly better the observations than a single layer.

\section{DISCUSSION}

\subsection{Lateral variation of the crustal thickness}

RF analysis shows a clear lateral variation in the crustal thickness along the Terre Adélie and George V Land coasts, as presented in Fig. 8. Each station samples a different block of the TAC and the Palaeozoic domain. The DRV station, in the Palaeoproterozoic domain, reveals a crustal thickness of about $43 \mathrm{~km}$ with possible reverberation at the Moho. This phenomenon can be explained by magmatic underplating that could have generated a thick mafic layer at the base of the crust, which is consistent with the observation of mafic magmatism synchronous with the 1.7 Ga metamorphic event (Monnier et al. 1996; Gapais et al. 2008). The depth of the Moho at DRV $(43 \mathrm{~km})$ is close to the $44 \mathrm{~km}$ depth in the amphibolite terrane where the PORMA station is installed. At the PIDGE station, in the granulite facies area of the TAC, the crust is estimated to be 40 $\mathrm{km}$ thick, slightly thinner than the amphibolite terrane. The similar crustal thicknesses at DRV, PORMA and PIDGE suggest that these three blocks are part of the same craton. Data recorded at the CORRE station, on the MSZ outcrop, indicate a crustal thickness of $36 \mathrm{~km}$. This is $8 \mathrm{~km}$ thinner than at the PORMA station, in the same amphibolite block, suggesting that this station could correspond to the craton border. RF analysis of the few events with backazimuths between $270^{\circ}$ and $360^{\circ}$ that sample the Fresnel zone into the TAC suggest a Moho at around $40 \mathrm{~km}$, which is deeper than the Moho depth $(36 \mathrm{~km})$ estimated from events in the northeast quadrant. This difference reinforces the hypothesis that the CORRE station in the MSZ is likely located at the edge of the TAC. Finally, to the east of the MSZ, the Palaeozoic block appears to be only $28 \mathrm{~km}$ thick, which is a common thickness for a non-cratonic continental crust, and has no strong intermediate-depth crustal boundary. Thus our seismic experiment provides arguments that the MSZ could correspond to a transition between the thick TAC (44-40 km at DRV, PORMA and PIDGE) and the much thinner Palaeozoic domain (28 $\mathrm{km}$ at PINGU). The crustal or lithospheric nature of the MSZ cannot be distinguished from RF alone, and is discussed in a subsequent section entitled 'Deep structure of the MSZ'. The Moho therefore appears to be affected by a $12 \mathrm{~km}$ offset between the Palaeozoic crust (PINGU) and the cratonic core (PIDGE). This crustal thickness change occurs over a distance of less than $100 \mathrm{~km}$ but is likely to be rather abrupt in view of the east and west Moho depths deduced from CORRE RFs. Satellite magnetic, gravity and subglacial topography data presented by Goodge \& Finn (2010), Aitken et al. (2014) and references therein also highlight that the TAC and the early Palaeozoic terranes constitute two different blocks and that their common boundary is situated at the MSZ. Our observations are obviously limited by the distance between seismic stations, so it is not possible to determine whether this variation corresponds to a gradual thinning or to a step-like transition. In the latter case, the MSZ may represent a palaeosuture along which the thinner
Palaeozoic lithosphere could have been accreted. This would indicate a transcurrent event that tectonically accreted two previously separated lithospheric blocks. However, the marked Moho offset observed at the MSZ does not allow us to conclude that its last activation (at $1.5 \mathrm{Ga}$ or during the Palaeozoic) was limited to a strike-slip component alone.

Our estimations of crustal thickness in the TAC and the Palaeozoic domain are larger than those summarized by Baranov \& Morelli (2013) for East Antarctica and by Chaput et al. (2014) for West Antarctica, respectively. However, the only seismic data used by Baranov \& Morelli (2013) from Terre Adélie and George V Land are from DRV (permanent station). Moho estimations in this region are thus extrapolations between widely spaced stations. Our study provides new constraints for Moho depth estimations in this area, which can be used in future models. Furthermore, our RF results are in agreement with the RF study of Lawrence et al. (2006) in the Transantarctic Mountains and surroundings, where they estimate that crustal thickness increases from $20 \pm 2 \mathrm{~km}$ in the Ross Sea (West Antarctica) to a maximum of $40 \pm 2 \mathrm{~km}$ beneath the crest of the Transantarctic Mountains, which form the boundary between East and West Antarctica.

\subsection{Antarctica-Australia lithospheric connection?}

These new results, particularly issued from RF analyses, provide the opportunity to compare the Moho depths observed in Terre Adélie and George V Land with those observed in south east Australia. This is of interest for matching large-scale structures between these two continents that were initially connected before the Gondwana breakup $150 \mathrm{Ma}$ ago, and the opening of the Southern Ocean. The TAC is inferred to have been connected to the Gawler Craton (Oliver \& Fanning 1997; Peucat et al. 1999; Fanning et al. 2002; Di Vincenzo et al. 2007). The Moho depth was estimated in the Gawler Craton at about $40 \mathrm{~km}$ by Collins (1991), Clitheroe et al. (2000) and between 40 and $45 \mathrm{~km}$ by Fontaine et al. (2013b). Moreover, all the authors highlight evidences of magmatic underplating beneath the Gawler Craton. Both the crustal thickness and the possible presence of underplating are therefore compatible with our results from the TAC. They provide new evidence for the connection between these two cratons, which is consistent with plate reconstructions from Williams et al. (2011). In this scenario, the Palaeozoic granitoid areas from George V Land would be associated with the Ross orogeny, which can be correlated to the Delamerian orogeny in south Australia (Flöttmann et al. 1993; Ireland et al. 1998). Works by Collins (1991), Shibutani et al. (1996) and Kennett et al. (2011) point out a Moho depth at 31 and $35 \mathrm{~km}$, respectively, in the Delamerian orogeny, that is, a crust which is between 5 and $10 \mathrm{~km}$ thinner relative to the Gawler Craton. These results are slightly different from our crustal estimation at PINGU, which argue for a more marked crustal thinning (of $12 \mathrm{~km}$ ) but interestingly, Vérard \& Stampfli (2013) suggest that the Delamerian and the Ross orogenies are slightly separated in time (about $20 \mathrm{Ma}$ ) and do not consist of the same terranes. These results therefore suggest that the step in the crustal thickness between Palaeoproterozoic and Palaeozoic domains is smaller in Australia than in Antarctica.

\subsection{Sublithospheric shearing associated to plate motion}

Seismic anisotropy beneath the studied area may result from sublithospheric mantle shearing induced by the displacement of the Antarctic plate relative to the deeper mantle. This process should 

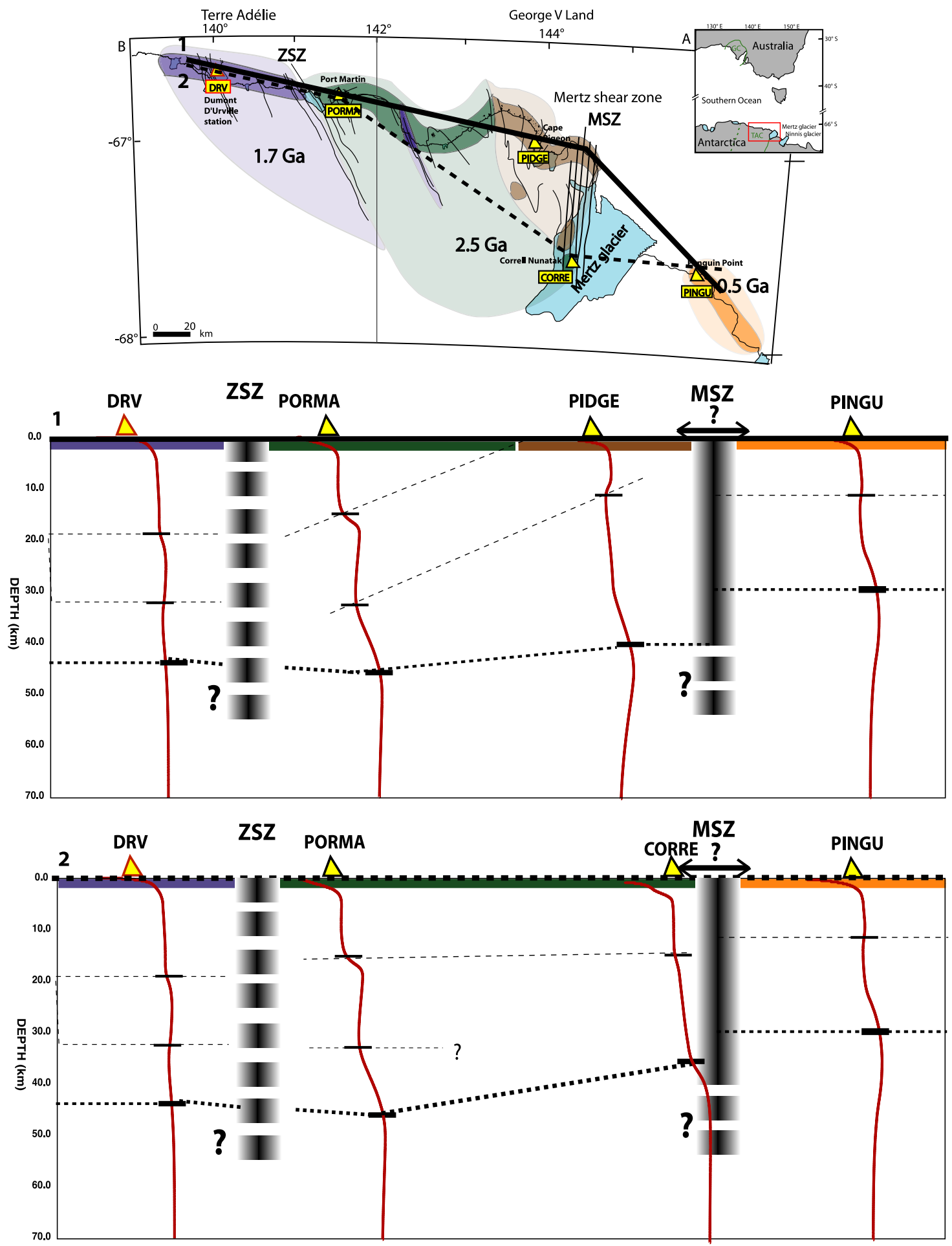

Figure 8. Synthetic cross-sections with 1-D shear wave velocity models derived from RF inversion from teleseismic earthquakes at the ArLiTA and DRV stations. Red lines are the average models of the best 1000 models derived from each station (see Fig. 4). Black lines represent the Moho and thin black lines represent internal structures in the crust. The thick dashed line at the CORRE station symbolize the depths of the Moho (40 km) estimated from RFs with backazimuths between $270^{\circ}$ and $360^{\circ}$ (fourth quadrant). See Fig. 1 for legend of the geological map. The potential depth extension of the shear zones are represented by broad dashed lines. The broad full line for the MSZ underlines the transition between the thick TAC crust (44-40 km at PIDGE) and the thin Palaeozoic terrains.

align the olivine's $a$-axes, and therefore the polarization direction of the fast split shear waves along directions resulting from the plate motion vector and the underlying unknown 'convection vector', corresponding to the regional flow induced by deep convection. For plates moving at velocities notably higher than that of the deep convection, $\Phi$ is expected to be close to the absolute plate motion, as observed, for instance, on the South Pacific Plate (e.g. Fontaine et al. 2007). When the plate is slow, which is clearly the case for the Antarctic Plate $\left(<2 \mathrm{~cm} \mathrm{yr}^{-1}\right)$, one can expect notable differences between $\Phi$ and the plate motion vector. For instance, Barruol \& 
Fontaine (2013) and Behn et al. (2004) report olivine $a$-axes oriented at a high angle to the plate motion vector from $S K S$ splitting measurements in the Indian Ocean and Debayle \& Ricard (2013) found no clear relationship between the directions of the surface wave anisotropy and the plate motion. Despite the fact that models of Antarctic Plate motion are poorly constrained and show a strong variability (see Fig. S3 for details about models of the Antarctic Plate motion), none of these models provides a good correlation with the E-W trend of the observed fast split directions. This suggests that, if the anisotropy is concentrated at asthenospheric depths, it results mainly from the shearing induced by the sublithospheric mantle convection and not by the only plate motion vector.

The surface wave anisotropic tomography (Debayle \& Ricard 2012, 2013) provides complementary large-scale information on the upper mantle structure and anisotropy in our studied area. Seismic velocities at 100 and $150 \mathrm{~km}$ depth indicate strong lateral velocity variations around $150^{\circ}$ longitude, which clearly mark the craton boundary. Strong anisotropies are also visible at 100 and $150 \mathrm{~km}$ depth, slightly decreasing at $200 \mathrm{~km}$ and vanishing at $300 \mathrm{~km}$ depth. The Rayleigh wave azimuthal anisotropy pattern in our study area exhibits fast directions oriented normal to the Australian and Antarctic continental margins and parallel to the oceanic expansion direction. This suggests that the anisotropy at asthenospheric depth is dominated at long wavelengths by the opening of the ocean basin and by the asthenospheric drag of the plate. In this tomography model, surface wave anisotropies clearly highlight the craton thickness and its eastern boundary, but do not show any clear margin-parallel fast anisotropic directions as observed from $S K S$ splitting. This suggests that $S K S$ waves sample a much more local structure than Rayleigh waves, which are sensitive to much larger scale structures of wavelengths of several hundreds of kilometres.

In summary, we propose that the observed anisotropy along the continental margin of Antarctica in Terre Adélie and George V Land is likely dominated by the local imprint of the rifting episode within the deep lithosphere. Anisotropy further south, within the continent, might reveal the frozen Archean and Palaeoproterozoic lithospheric structure, and anisotropy further north, in the suboceanic upper mantle, might be dominated by large-scale mantle convection processes and by the plate drag.

\subsection{Mantle flow: Archean-Palaeoproterozoic versus Cretaceous}

SKS splitting observed at the stations located on the TAC show that the fast split shear waves are mostly oriented parallel to the continental margin, and at a fairly high angle to the regional crustal structures that trend roughly NW-SE to N-S. This anisotropy pattern is similar to that previously found by Reading \& Heintz (2008) at seismological stations in East Antarctica. Interestingly, these authors found different anisotropy signatures at stations located close to the continental margin compared to those located farther south within the continent. They explained the margin-parallel anisotropy as possibly reflecting trans-tensional deformation associated with the initial stages of the continental break-up of Gondwana, with the rifting episode thinning the mantle part of the lithosphere and subsequently erasing the pre-existing, frozen-in anisotropy. This hypothesis is in agreement with the model of Vauchez et al. (2000) which proposes that asthenospheric flow is dominating within the rift axis, generating a fast axis of anisotropy oriented parallel to the rift in the case of transtensional lithospheric rupture. Mantle anisotropy parallel to a rift margin is also observed in Papua New Guinea
(Eilon et al. 2014) and along the East African Rift (Hammond et al. 2014). Reading \& Heintz (2008) also proposed that this rifting could have been controlled by pre-existing regional lithospheric structures through the anisotropic mechanical behaviour of the plate (Vauchez et al. 1997; Tommasi \& Vauchez 2001). However, there is no evidence of $\mathrm{E}-\mathrm{W}$ lithospheric pervasive structures predating the southern ocean rifting in our studied region. However, Ménot et al. (2007) and Bascou et al. (2013) measured NS to $\mathrm{N} 160^{\circ} \mathrm{E}$ penetrative structures. In the model from Reading \& Heintz (2008), anisotropy close to the continent margin could therefore reflect the Cretaceous rifting tectonics and the lithosphere thinning, and the anisotropy signature visible at a larger distance to the continental shelf could be related to pre-existing Archean-Palaeoproterozoic pervasive structures frozen in the lithosphere. This observation is also in agreement with data compiled by Barklage et al. (2009) at various seismic stations of East Antarctica.

It must be noted however, that our results might also be compatible with the presence of two anisotropic layers comprising a dominant lower layer characterized by an E-W trending $\Phi$ and a high $\delta t$, related to the Cretaceous early-rifting stage, and an upper layer with a NW-SE to NS-trending $\Phi$ and a low $\delta t$, that could reflect the frozen pervasive Archean-Palaeoproterozoic deformation of the lithosphere. A similar model with two distinct layers reflecting a recent asthenospheric flow underlying an old pervasive deformation in the upper mantle was proposed by Usui et al. (2007) to interpret $S K S$ splitting data in the Lützow-Holm Bay region in East Antarctica. A scenario such as this, with fast directions with perpendicular orientations and a dominant lower $\delta$ t may correctly explain our measurements and reconcile the simultaneous presence of Archean-Palaeoproterozoic and Cretaceous deformation. However, a model like this would fail to explain the fact that the early stage of the rifting could have been controlled by pre-existing regional lithospheric structures and by pervasive mechanical anisotropy of the lithosphere, as proposed by Vauchez et al. (1997) and recently modelled by Knoll et al. (2009).

\subsection{Deep signature of the MSZ}

Following the previous discussion, the fact that the MSZ is oriented at a large angle to the continental margin may conceal its intrinsic anisotropic signature by seemingly revealing only one single anisotropic structure instead of two perpendicularly oriented anisotropies. However, there is no strong difference in $S K S$ anisotropy azimuth or delay time between stations on either side of and above the MSZ, according to the small number or good events recorded by the temporary network. Therefore, our observation does not argue for strong pervasive mantle deformation associated with the shear zone activity. However, Moho depth differences between the craton and the Palaeozoic domain on each side of the MSZ reveal a tectonic collage at this location that might have occurred during a transcurrent event. This apparent contradiction may be explained by two hypotheses: (1) the structure of the MSZ root in the mantle (Vauchez et al. 2012) has been erased during the rifting of the southern ocean, or (2) the MSZ is flattening at depth, as proposed by Coward \& Daly (1984) for major shear zones situated at boundaries of African cratons, for example in Botswana.

\section{CONCLUSIONS}

Analysis of RFs and shear wave splitting at temporary ArLiTA stations and the permanent DRV GEOSCOPE station allows us to 
better constrain the crustal structures and mantle anisotropy of the Terre Adélie and George V Land regions. Our study has shown the following.

(1) The MSZ corresponds to a transition between the thick TAC crust (44-40 km at DRV, PORMA and PIDGE), likely affected by magmatic underplating, and the much thinner Palaeozoic crust (28 $\mathrm{km}$ at PINGU). The Moho therefore appears to accommodate a 12 $\mathrm{km}$ offset between the Palaeozoic crust (PINGU) and the cratonic core (PIDGE).

(2) Moho depths in the TAC are similar to estimations of crustal thicknesses in the Gawler Craton. However, the Moho at the PINGU station, in the Ross orogeny, appears to be shallower than in the Delamerian orogeny in south Australia. This suggests NS variability of the structures along the belt and/or two different orogenic episodes between Ross and Delamerian events, albeit very close in time.

(3) $S K S$ anisotropy shows dominant fast directions parallel to the coastline along the Antarctic continental margin of Terre Adélie and George V Land. This suggests that the rifting episode may have erased part of the frozen-in pervasive lithospheric structure and may have left a dominant rift-parallel imprint beneath the margin of the Antarctic continent.

\section{ACKNOWLEDGEMENTS}

This work was supported by the French polar institute (IPEV, Institut Polaire Paul Emile Victor). Special thanks to Alain Pierre for his efficient support in the seismic station design and for the help with the station's deployment. Portable seismometers were provided by the French national pool of portable seismic instruments SisMob-RESIF of the CNRS-INSU and seismological data will be available at the French RESIF archive centre http://portal.resif.fr/. ArLiTA also benefited of the support of the INSU-SYSTER program. Thanks are due to the GEOSCOPE network for the availability and the high quality data of DRV station. More information on the ArLiTA project at http://dossier.univ-st-etienne.fr/arlita/www/.

\section{REFERENCES}

Aitken, A.R.A. et al., 2014. The subglacial geology of Wilkes Land, East Antarctica, Geophys. Res. Lett., 41(7), 2390-2400.

Ammon, C.J., 1991. The isolation of receiver effects from teleseismic P weveforms, Bull. seism. Soc. Am., 81(6), 2504-2510.

Ammon, C.J., Randall, G.E. \& Zandt, G., 1990. On the Nonuniqueness of receiver function inversions, J. geophys. Res., 95(B10), 15 303-15 318.

Baranov, A. \& Morelli, A., 2013. The Moho depth map of the Antarctica region, Tectonophysics, 609, 299-313.

Barklage, M., Wiens, D.A., Nyblade, A. \& Anandakrishnan, S., 2009. Upper mantle seismic anisotropy of South Victoria Land and the Ross Sea coast, Antarctica from SKS and SKKS splitting analysis, Geophys. J. Int., 178(2), 729-741.

Barruol, G. \& Fontaine, F.R., 2013. Mantle flow beneath La Réunion hotspot track from SKS splitting, Earth planet. Sci. Lett., 362, 108-121.

Barruol, G. \& Hoffmann, R., 1999. Upper mantle anisotropy beneath the Geoscope stations, J. geophys. Res., 104(B5), 10 757-10 773.

Barruol, G., Silver, P.G. \& Vauchez, A., 1997. Seismic anisotropy in the eastern United States: deep strcuture of a complex continental plate, $J$. geophys. Res., 102(B4), 8329-8348.

Barruol, G., Bonnin, M., Pedersen, H., Bokelmann, G.H.R. \& Tiberi, C., 2011. Belt-parallel mantle flow beneath a halted continental collision: the Western Alps, Earth planet. Sci. Lett., 302(3-4), 429-438.

Barruol, G., Cordier, E., Bascou, J., Fontaine, F.R., Legrésy, B. \& Lescarmontier, L., 2013. Tide-induced microseismicity in the Mertz glacier grounding area, East Antarctica, Geophys. Res. Lett., 40, 1-5.
Bascou, J., Henry, B., Ménot, R.-P., Funaki, M. \& Barruol, G., 2013. Contribution of AMS measurements in understanding the migmatitic terrains of Pointe Géologie, Terre Adélie (East-Antarctica), Tectonophysics, 603, 123-135.

Behn, M.D., Conrad, C.P. \& Silver, P.G., 2004. Detection of upper mantle flow associated with the African Superplume, Earth planet. Sci. Lett., 224(3-4), 259-274.

Boger, S.D., 2011. Antarctica - before and after Gondwana, Gondwana Res., 19(2), 335-371.

Bowman, J.R. \& Ando, M., 1987. Shear-wave splitting in the upper-mantle wedge above the Tonga subduction zone, Geophys. J. Int., 88(1), 25-41.

Di Vincenzo, G., Talarico, F. \& Kleinschmidt, G., 2007. An ${ }^{40} \mathrm{Ar}-{ }^{39} \mathrm{Ar}$ investigation of the Mertz Glacier area (George V Land, Antarctica): implications for the Ross Orogen-East Antarctic Craton relationship and Gondwana reconstructions, Precambrian Res., 152(3-4), 93-118.

Chaput, J. et al., 2014. The crustal thickness of West Antarctica, J. geophys. Res. Solid Earth, 119(1), 378-395.

Clitheroe, G., Gudmundsson, O. \& Kennett, B.L.N., 2000. The crustal thickness of Australia, J. geophys. Res., 105(B6), 13697, doi:10.1029/1999JB900317.

Collins, C.D.N., 1991. The nature of the crust-mantle boundary under Australia from seismic evidence, Aust. Lithosph., 17, 67-80.

Coward, M.P. \& Daly, M.C., 1984. Crustal lineaments and shear zones in Africa: their relationship to plate movements, Precambrian Res., 24, $27-45$.

Debayle, E. \& Ricard, Y., 2012. A global shear velocity model of the upper mantle from fundamental and higher Rayleigh mode measurements, $J$. geophys. Res., 117(B10), B10308, doi:10.1029/2012JB009288.

Debayle, E. \& Ricard, Y., 2013. Seismic observations of large-scale deformation at the bottom of fast-moving plates, Earth planet. Sci. Lett., 376, $165-177$.

Debayle, E., Kennett, B. \& Priestley, K., 2005. Global azimuthal seismic anisotropy and the unique plate-motion deformation of Australia, Nature, 433(7025), 509-512.

Dietrich, R., Rülke, A., Ihde, J., Lindner, K., Miller, H., Niemeier, W., Schenke, H.-W. \& Seeber, G., 2004. Plate kinematics and deformation status of the Antarctic Peninsula based on GPS, Glob. planet. Change, 42(1-4), 313-321.

Duclaux, G. et al., 2008. Superimposed Neoarchaean and Paleoproterozoic tectonics in the Terre Adélie Craton (East Antarctica): evidence from Th$\mathrm{U}-\mathrm{Pb}$ ages on monazite and ${ }^{40} \mathrm{Ar} /{ }^{39} \mathrm{Ar}$ ages, Precambrian Res., 167(3-4), 316-338.

Eilon, Z., Abers, G.A., Jin, G. \& Gathery, J.B., 2014. Anisotropy beneath a highly extended continental rift, Geochem., Geophys. Geosyst., 15, $545-564$.

Fanning, C., Ménot, R.P., Peucat, J. \& Pelletier, A., 2002. A closer examination of the direct links between Southern Australia and Terre Adélie and George V Land, Antarctica, in Proceedings of the 16th Australian Geological Convention, Adelaide.

Flöttmann, T., Gibson, G.M. \& Kleinschmidt, G., 1993. Structural continuity of the Ross and Delamerian orogens of Antarctica and Australia along the margin of the paleo-Pacific, Geology, 21, 319-322.

Fontaine, F.R., Barruol, G., Tommasi, A. \& Bokelmann, G.H.R., 2007. Upper-mantle flow beneath French Polynesia from shear wave splitting, Geophys. J. Int., 170(3), 1262-1288.

Fontaine, F.R., Tkalčić, H. \& Kennett, B.L.N., 2013a. Imaging crustal structure variation across southeastern Australia, Tectonophysics, 582, $112-125$.

Fontaine, F.R., Tkalčić, H. \& Kennett, B.L.N., 2013b. Crustal complexity in the Lachlan Orogen revealed from teleseismic receiver functions, Aust. $J$. Earth Sci., 60(3), 413-430.

Gapais, D., Pelletier, A., Ménot, R.-P. \& Peucat, J.-J., 2008. Paleoproterozoic tectonics in the Terre Adélie Craton (East Antarctica), Precambrian Res., 162(3-4), 531-539.

Gibson, G.M., Totterdell, J.M., White, L.T., Mitchell, C.H., Stacey, A.R., Morse, M.P. \& Whitaker, A., 2013. Pre-existing basement structure and its influence on continental rifting and fracture zone development along Australia's southern rifted margin, J. Geol. Soc. Lond., 170(2), 365-377. 
Goodge, J.W. \& Finn, C.A., 2010. Glimpses of East Antarctica: aeromagnetic and satellite magnetic view from the central Transantarctic Mountains of East Antarctica, J. geophys. Res., 115(B9), B09103, doi:10.1029/2009JB006890.

Gripp, A.E. \& Gordon, R.G., 1990. Current plate velocities relative to the hotspots incorporating the Nuvel-1 global plate motion model, Geophys. Res. Lett., 17(8), 1109-1112.

Gripp, A.E. \& Gordon, R.G., 2002. Young tracks of hotspots and current plate velocities, Geophys. J. Int., 150(2), 321-361.

Hammond, J.O.S., Kendall, J.-M., Wookey, J., Stuart, G.W., Keir, D. \& Ayele, A., 2014. Differentiating flow, melt, or fossil seismic anisotropy beneath Ethiopia, Geochem., Geophys. Geosyst., 15, 1-17.

Hansen, S. E. et al., 2014. Imaging the Antarctic mantle using adaptively parameterized $P$-wave tomography: evidence for heterogeneous structure beneath West Antarctica, Earth planet. Sci. Lett., 408, 66-78.

Harley, S.L., Fitzsimons, I.C.W. \& Zhao, Y., 2013. Antarctica and supercontinent evolution: historical perspectives, recent advances and unresolved issues, Geol. Soc. Lond., Spec. Publ., 383(1), 1-34.

Haskell, N.A., 1953. The dispersion of surface waves on multilayered media, Bull. seism. Soc. Am., 43, 17-34.

Ireland, T.R., Flöttmann, T., Fanning, C.M., Gibson, G.M. \& Preiss, W.V., 1998. Development of the early Paleozoic Pacific margin of Gondwana from detrital-zircon ages across the Delamerian orogen, Geology, 26(3), 243-246.

Julià, J., Ammon, C.J., Herrmann, R.B. \& Correig, A.M., 2000. Joint inversion of receiver function and surface wave dispersion observations, Geophys. J. Int., 143, 99-112.

Kennett, B.L.N., Salmon, M., Saygin, E. \& the AusMoho Working Group, 2011. AusMoho: the variation of Moho depth in Australia, Geophys. $J$. Int., 187(2), 946-958.

Kleinschmidt, G. \& Talarico, F., 2000. The Mertz Shear Zone, Terra Antarct. Reports, 5.

Knoll, M., Tommasi, A., Logé, R.E. \& Signorelli, J.W., 2009. A multiscale approach to model the anisotropic deformation of lithospheric plates Geochem. Geophys. Geosyst., 10(8), doi:10.1029/2009GC002423.

Kreemer, C., 2009. Absolute plate motions constrained by shear wave splitting orientations with implications for hot spot motions and mantle flow, J. geophys. Res., 114, B10405, doi:10.1029/2009JB006416.

Kreemer, C., Holt, W.E. \& Haines, A.J., 2003. An integrated global model of present-day plate motions and plate boundary deformation, Geophys. J. Int., 154(1), 8-34.

Langston, C.A., 1977. Corvallis, Oregon, Crustal and upper mantle receiver structure from teleseismic $\mathrm{P}$ and $\mathrm{S}$ waves, Bull. seism. Soc. Am., 67(3), 713-724.

Langston, C.A., 1979. Structure under Mount Rainier, Washington, Inferred from teleseismic body waves, J. geophys. Res., 84(9), 4749-4762.

Lawrence, J.F., Wiens, D.A., Nyblade, A.A., Anandakrishnan, S., Shore, P.J. \& Voigt, D., 2006. Crust and upper mantle structure of the Transantarctic Mountains and surrounding regions from receiver functions, surface waves, and gravity: implications for uplift models, Geochem. Geophys. Geosyst., 7(10), doi:10.1029/2006GC001282.

Ligorria, P. \& Ammon, C.J., 1999. Iterative deconvolution and receiverfunction estimation, Bull. seism. Soc. Am., 89(5), 1395-1400.

Mainprice, D. \& Barruol, G. \&Ben Ismail, W., 2000. The seismic anisotropy of the Earth's mantle: from single crystal to polycrystal, in Earth's Deep Interior: Mineral Physics and Tomography From the Atomic to the Global Scale, eds Karato, S.-I., Forte, A., Liebermann, R., Masters, G. \& Stixrude, L., American Geophysical Union, doi:10.1029/GM117p0237.

Margheriti, L., Lucente, F.P. \& Pondrelli, S., 2003. SKS splitting measurements in the Apenninic-Tyrrhenian domain (Italy) and their relation with lithospheric subduction and mantle convection, J. geophys. Res., 108(B4), 2218, doi:10.1029/2002JB001793.

Ménot, R.-P., Pêcher, A., Rolland, Y., Peucat, J.-J., Pelletier, A., Duclaux, G. \& Guillot, S., 2005. Structural setting of the Neoarchean Terrains in the Commonwealth Bay Area $\left(143-145^{\circ} \mathrm{E}\right)$, Terre Adélie Craton, East Antarctica, Gondwana Res., 8(1), 1-9.

Ménot, R.P., 2007. Geology of the Terre Adélie Craton $\left(135-146^{\circ} \mathrm{E}\right)$, in Antarctica: A Keystone in a Changing World-Online Proceedings of the 10th ISAES, p. 1047, eds Cooper, A.K. et al., USGS Open-File Report 2007-1047.

Mikhal'sky, E.V., 2008. Main stages and geodynamic regimes of the Earth's crust formation in East Antarctica in the Proterozoic and Early Paleozoic, Geotectonics, 42(6), 413-429.

Monnier, O., Ménot, R.-P., Peucat, J.J., Fanning, M. \& Giret, A., 1996. Actualisation des données géologiques sur Terre Adélie (Antarctique Est): mise en évidence d'un collage tectonique au Protérozoïque, C.R. Acad. Sci. Paris, T322, 55-62.

Morelli, A. \& Danesi, S., 2004. Seismological imaging of the Antarctic continental lithosphere: a review, Glob. planet. Change, 42(1-4), $155-165$.

Morgan, W.J. \& Morgan, J.P., 2007. Plate velocities in the hotspot reference frame, Geol. Soc. Am. Bull., 2430(04), 65-78.

Müller, C., 2001. Upper mantle seismic anisotropy beneath Antarctica and the Scotia Sea region, Geophys. J. Int., 147, 105-122.

Müller, R.D., Royer, J. \& Lawver, L.A., 1993. Revised plate motions relative to the hotspots from combined Atlantic and Indian Ocean hotspot tracks, Geology, 21, 275-278.

Nicolas, A. \& Christensen, N.I., 1987. Formation of anisotropy in upper mantle peridotites: A review, in Composition, Structure and Dynamics of the Lithosphere, pp. 111-123, eds Froidevaux, K. \& Fuchs, C., Asthenosphere System.

Oliver, R. \& Fanning, C., 1997. Australia and Antarctica: precise correlation of Paleoproterozoic terrains, in The Antarctic Region: Geological Evolution and Processes, pp. 163-172, ed. Ricci, C.A., Terra Antarctic Publication.

Oliver, R. \& Fanning, C., 2002. Proterozoic geology east and southeast of Commonwealth Bay, George V Land, Antarctica, and its relationship to that of adjacent Gondwana terranes, in Antarctica at the Close of the Millenium, pp. 51-58, The Royal Society of New Zealand.

Peucat, J.J., Ménot, R.P., Monnier, O. \& Fanning, C., 1999. The Terre Adélie basement in the East-Antarctica Shield: geological and isotopic evidence for a major $1.7 \mathrm{Ga}$ thermal event; comparison with the Gawler Craton in South Australia, Precambrian Res., 94, 205-224.

Pondrelli, S., Margheriti, L. \& Danesi, S., 2006. Seismic anisotropy beneath Northern Victoria land from SKS splitting analysis, in Antarctica: Contributions to Global Earth Sciences, pp. 155-162, eds Füterrer, D., Damaske, D., Kleinschmidt, G.M.H. \& Tessensohn, F., Springer-Verlag.

Reading, A.M., 2004. The seismic structure of Wilkes Land/Terre Adelie, East Antarctica and comparison with Australia: first steps in reconstructing the deep lithosphere of Gondwana, Gondwana Res., 7(1), 21-30.

Reading, A.M. \& Heintz, M., 2008. Seismic anisotropy of East Antarctica from shear-wave splitting: spatially varying contributions from lithospheric structural fabric and mantle flow?, Earth planet. Sci. Lett., 268(34), 433-443.

Ritzwoller, M.H., Shapiro, N.M., Levshin, A.L. \& Leahy, G.M., 2001. Crustal and upper mantle structure beneath Antarctica and surrounding oceans, J. geophys. Res., 106(12), 30 645-30 670.

Roult, G. \& Rouland, D., 1994. Antarctica I: deep structure investigations inferred from seismology; a review, Phys. Earth planet. Inter., 84, 15-32.

Roult, G., Rouland, D. \& Montagner, J.P., 1994. Antarctica II: upper-mantle structure from velocities and anisotropy, Phys. Earth planet. Inter., 84(14), 33-57.

Salimbeni, S., Pondrelli, S., Danesi, S. \& Morelli, A., 2010. Seismic anisotropy of the Victoria Land region, Antarctica, Geophys. J. Int., 182, 421-432.

Sambridge, M., 1999a. Geophysical inversion with a neighbourhood algorithm-I. Searching a parameter space, Geophys. J. Int., 138(2), 479-494.

Sambridge, M., 1999b. Geophysical inversion with a neighbourhood algorithm-II. Appraising the ensemble, Geophys. J. Int., 138(3), 727-746.

Shibutani, T., Sambridge, M. \& Kennett, B., 1996. Genetic algorithm inversion for receiver functions with application to crust and uppermost mantle structure beneath Eastern Australia, Geophys. Res. Lett., 23(14), $1829-1832$. 
Silver, P.G., 1996. Seismic anisotropy beneath the continents: probing the depths of geology, Annu. Rev. Earth planet. Sci., 24, 385-432.

Silver, P.G. \& Chan, W.W., 1991. Shear wave splitting and sub continental mantle deformation, J. geophys. Res., 96(B10), 16 429-16 454.

Stillwell, F.L., 1918. The metamorphic rocks of Adélie Land, Australian Antarctic Expedition 1911-14. Scientific Reports, Ser A. III-Geology.

Talarico, F. \& Kleinschmidt, G., 2003. Structural an metamorphic evolution of the Mertz Shear Zone (East Antarctic Craton, Geroge V Land): implications for Australia/Antarctica correlations and East Antarctic craton/Ross orogen relationships, Terra Antarct., 10, 229-248.

Thomson, W.T., 1950. Transmission of Elastic waves through a stratified solid medium, J. appl. Phys., 21, 89-93.

Tkalčić, H., Pasyanos, M.E., Rodgers, A.J., Gök, R., Walter, W.R. \& AlAmri, A., 2006. A multistep approach for joint modeling of surface wave dispersion and teleseismic receiver functions: implications for lithospheric structure of the Arabian Peninsula, J. geophys. Res., 111, B11311, doi:10.1029/2005JB004130.

Tkalčić, H., Chen, Y., Liu, R., Zhibin, H., Sun, L. \& Chan, W., 2011. Multistep modelling of teleseismic receiver functions combined with constraints from seismic tomography: crustal structure beneath southeast China, Geophys. J. Int., 187(1), 303-326.

Tommasi, A. \& Vauchez, A., 2001. Continental rifting parallel to ancient collisional belts: an effect of the mechanical anisotropy of the lithospheric mantle, Earth planet. Sci. Lett., 185, 199-210.

Usui, Y., Kanao, M., Kubo, A., Hiramatsu, Y. \& Negishi, H., 2007. Upper mantle anisotropy from teleseismic SKS splitting beneath Lützow-Holm Bay region, East Antarctica, U. S. Geological Survey and The National Academies; USGS OF-2007-1047, Short Research Paper 013, pp. 2-5.

Vauchez, A., Barruol, G. \& Tommasi, A., 1997. Why do continents break-up parallel to ancient orogenic belts?, Terra Nov., 9(2), 62-66.

Vauchez, A., Tommasi, A., Barruol, G. \& Maumus, J., 2000. Upper mantle deformation and seismic anisotropy in continental rifts, Phys. Chem. Earth, 25(2), 111-117.

Vauchez, A., Tommasi, A. \& Mainprice, D., 2012. Faults (shear zones) in the Earth's mantle, Tectonophysics, 558-559, 1-27.

Veevers, J.J., 2012. Reconstructions before rifting and drifting reveal the geological connections between Antarctica and its conjugates in Gondwanaland, Earth-Sci. Rev., 111(3-4), 249-318.

Vérard, C. \& Stampfli, G., 2013. Geodynamic Reconstructions of the Australides-1: Palaeozoic, Geosciences, 3(2), 311-330.

Walker, K.T., Bokelmann, G.H.R., Klemperer, S.L. \& Bock, G., 2005. Shearwave splitting around the Eifel hotspot: evidence for a mantle upwelling, Geophys. J. Int., 163(3), 962-980.

Williams, S.E., Whittaker, J.M. \& Müller, R.D., 2011. Full-fit, palinspastic reconstruction of the conjugate Australian-Antarctic margins, Tectonics, 30(6), TC6012, doi:10.1029/2011TC002912.

Wüstefeld, A. \& Bokelmann, G., 2007. Null detection in shear-wave splitting measurements, Bull. seism. Soc. Am., 97(4), 1204-1211.

Wüstefeld, A., Bokelmann, G., Zaroli, C. \& Barruol, G., 2008. SplitLab: a shear-wave splitting environment in Matlab, Comput. Geosci., 34(5), 515-528.

Wüstefeld, A., Bokelmann, G. \& Barruol, G., 2010. Evidence for ancient lithospheric deformation in the East European Craton based on mantle seismic anisotropy and crustal magnetics, Tectonophysics, 481(1-4), $16-28$.

\section{SUPPORTING INFORMATION}

Additional Supporting Information may be found in the online version of this article:
Figure S1. Comparison between results obtained from four-layers (left-hand side), an Australian-type six-layers (centre) and a different six-layers seismic velocity input model. For each station, both the plot showing the ensemble of crustal models and the observed (in black) and predicted (in red) radial RF for the best model from the NA inversion are represented. Plots show the best 100 or 1000 models in yellow and green, with the colour being logarithmically proportional to model number. The colour scale shows the increase in data fit from yellow to green. The solid red line represents the mean model.

Figure S2. Observed radial RFs and stacked RF at the DRV station for 34 individual events.

Figure S3. Synthesis of APM models for the Antarctic plate (arrows) and mean direction of $S K S$ anisotropy (red line). No correlation can be made between one of these Antarctica plate motion estimations and the E-W trend of the $S K S$ anisotropy. APM models are:

$*$ Dietrich et al. (2004) (black) show trends close to $\mathrm{N} 144^{\circ} \mathrm{E}$ and velocities of $1.4 \mathrm{~cm} \mathrm{yr}^{-1}$. This result is close to the model of GRSM (blue) (Kreemer et al. 2003) N147 ${ }^{\circ} \mathrm{E}$ and 1.44, NNR (N147 and $2.08 \mathrm{~cm} \mathrm{yr}^{-1}$ ) that assumes the absence of lithospheric net rotation. *HS2-Nuvel1 in orange (Gripp \& Gordon 1990) and HS3-Nuvel1a in green (Gripp \& Gordon 2002) APM models trend close to $\mathrm{NS}\left(\mathrm{N} 009^{\circ} \mathrm{E}\right.$ and $\mathrm{N} 003^{\circ} \mathrm{W}$, respectively) at velocities of $1.2-1.4$ $\mathrm{cm} \mathrm{yr}^{-1}$, respectively. These models are dominated by the Pacific hotspots and the motion of the Antarctic Plate is therefore poorly constrained.

*APM models published by Morgan \& Morgan (2007) and Müller et al. (1993) (pink and red, respectively) trend towards $\mathrm{N} 69^{\circ} \mathrm{E}$ and $\mathrm{N} 62^{\circ} \mathrm{E}$ at $\mathrm{DRV}$, respectively at velocities of 1.2 and $0.7 \mathrm{~cm} \mathrm{yr}^{-1}$. These models take into account the Indo-Atlantic hotspots and should provide better constraints on the Antarctic Plate motion.

*GSRM-APM-1 (Kreemer 2009) trends $\mathrm{N} 104^{\circ} \mathrm{E}$ at a very low velocity of $0.2 \mathrm{~cm} \mathrm{yr}^{-1}$. This model is based on the minimization of the $S K S$ split direction observations, assuming an asthenospheric origin of anisotropy induced by the plate motion (http://gji.oxfordjournals.org/lookup/suppl/doi:10.1093/gji/ ggu430/-/DC1).

Table S1. Individual measurements of $S K S$ splitting. From left to right: date of the event (date), station where the event is recorded (sta), studied phase (phase), backazimuth of the event (baz), inclination of the wave (inc), applied filter (filter), direction of anisotropy and delay time with error bars estimated with rotation-correlation methods (RC, dtRC), minimum energy ( $\mathrm{SC}, \mathrm{dtSC}$ ) and minimum eigenvalues (EV, dtEV), automatic quality factor (autoQ) and manual quality factor (manualQ).

Please note: Oxford University Press is not responsible for the content or functionality of any supporting materials supplied by the authors. Any queries (other than missing material) should be directed to the corresponding author for the article. 